\title{
Introduction. A new field: comparative law and regulation
}

\author{
Francesca Bignami
}

When individuals post their photographs, shopping habits, and other personal data to social networking sites they are tracked and potentially harassed by the scores of corporate actors with access to their data. As governments worldwide have sprung into action to address this regulatory problem, industry groups and consumer advocates have also mobilized. To give but one example, in the past three years, the world's leading social networking company has defended lawsuits claiming unfair consumer tracking in the United States and the European Union (EU), has settled administrative and civil enforcement actions brought by the U.S. Federal Trade Commission, the Belgian Data Protection Authority, and the Hamburg Data Protection Authority, and has lobbied for looser consumer-tracking rules in the European Union, the United States, Latin American countries, and the Asia-Pacific Economic Cooperation system. ${ }^{1}$ Although there are substantial limits on what social networking sites can do with personal data in the European Union and many Latin American countries, there are relatively few restrictions in the United States and various Asian jurisdictions.

Parabens are a group of chemicals widely used in cosmetics and personal care products. Although they significantly extend the shelf life of creams and sprays, they have also been linked to cancer and other types of health concerns. The regulatory battle over whether to ban or restrict their use is occurring in legislatures, administrative agencies, and international organizations throughout the world. Multinational corporations, members of the scientific community, and environmental and consumer groups have sparred over parabens in a vast array of venues-to name just a few, the

1 In re: Facebook Internet Tracking Litigation, 844 F. Supp. 2d 1374 (J.D.M.L. 2012); Case C-362/14, Schrems v. Data Protection Commissioner, 2013 WL 614CJ0362 (Oct. 6, 2015); In re Facebook, Inc., FTC File No. 092 3184, No. C-4365 (F.T.C. July 27, 2012); Commissie voor de bescherming van de persoonlijke levenssfeer (Belgian Data Protection Commission), Recommendation no. 04/2015 (May 13, 2015); Hamburgischen Beauftragten für Datenschutz und Informationsfreiheit (Hamburg Data Protection Authority), Press Release: Facebook's Biometric Database Continues To Be Unlawful (Nov. 10, 2011); Proposal for a Regulation of the European Parliament and of the Council on the Protection of Individuals with Regard to the Processing of Personal Data and on the Free Movement of Such Data (General Data Protection Regulation), COM (2012) 11 final (Jan. 25, 2012); The White House, Consumer Data Privacy in a Networked World: A Framework for Protecting Privacy and Promoting Innovation in the Global Economy 15-18 (2012); Camila Tobón, Data Privacy Laws in Latin America: An Overview, 44 International Law News 1 (2015) (reviewing laws of Argentina, Chile, Colombia, Costa Rica, Mexico, Nicaragua, Paraguay, Peru, and Uruguay); Asia-Pacific Economic Cooperation (APEC), The Cross Border Privacy Rules System: Promoting Consumer Privacy and Economic Growth Across the APEC Region (Sept. 5, 2013). 
U.S. Environmental Protection Agency, the European Commission, the Danish Environmental Protection Agency, the United Nations Environment Programme, and the Association of Southeast Asian Nations. While regulators in Europe and parts of Asia have recently banned or restricted certain parabens in cosmetics, regulators in the United States, China, and Latin American countries continue to impose no limits and might very well bring a challenge to parabens regulation in the World Trade Organization (WTO). ${ }^{2}$

These are but two examples of the global regulatory process. Regulatory problems are no longer confined to specific countries. By virtue of how global communications networks operate, a single social networking site can be used by individuals anywhere and trigger legal action in a host of jurisdictions. Multinational cosmetics corporations sell the same products throughout the globe and therefore regulators everywhere are called upon to assess their safety. The process, however, by which these national and international jurisdictions decide common regulatory problems bears little resemblance to the domestic regulatory process. There is no world government with the power to impose a single set of principles, institutions, and procedures on the multiple jurisdictions, and therefore the global regulatory process is characterized as much by diversity and discord as it is by coordination and convergence.

As of yet, the legal discipline has failed to develop a subfield dedicated to understanding the global regulatory process. The reason for the lag between the contemporary reality and the organization of research and knowledge building in the academy is related to the nineteenth century roots of the legal discipline. The different subfields of law that prevail still today were carved out in the heyday of the nation state: private law to regulate market-based and other private relations, constitutional law as the basic framework for the organization of the state, administrative law to govern public administration, criminal law for the police and prosecutors, and international law for inter-state relations in the international sphere. Comparative law, devoted to understanding the law of multiple jurisdictions, was subdivided into these different categories and was almost exclusively focused on private law, in particular the contract law essential to the global commerce of the nineteenth and twentieth centuries. What is more, comparative law was segregated from international law, conceived as operating in isolation from the internal law of the nation state.

The global regulatory process, a quintessentially twenty-first-century phenomenon, defies these nineteenth century disciplinary boundaries. To begin with, regulation is an inherently instrumental activity that is undertaken by a variety of public, and increasingly private, bodies and therefore cuts across many of the traditional subfields of law-constitutional law, administrative law, civil procedure, criminal procedure, and different types of private law. More to the point of the global character of contemporary

2 Commission Regulation 358/2014, 2014 O.J. (L 107) 5 (EU); Commission Regulation 1004/2014, 2014 O.J. (L 282) 5 (EU); Statutory order on restriction on import, sale and use of certain parabens in cosmetic products for children under 3 years (Denmark, Oct. 11, 2013); ASEAN Cosmetic Directive, Annex II (Association of South East Asian Nations); Taylor L. Kraus, Caring About Personal Care Products: Regulation in the United States, the European Union, and China in the Age of Global Consumption, 33 Wisconsin International Law Journal 167 (2015) (reviewing law of the U.S., EU, and China). 
regulation, what field of law is important for the regulatory function can vary enormously between jurisdictions. It may be that in some places a rule such as a ban on consumer tracking is enforced largely by criminal prosecutors, under the principles of criminal procedure, while in other places administrative proceedings, governed by administrative law, are more important. And the law of both national and international jurisdictions is critical. A Danish rule banning parabens can easily be undone by a contrary EU rule or an adverse WTO ruling. In sum, the conventional boundaries that separate the different subfields of law operate as a real obstacle to understanding how global regulatory problems are handled by the multiple legal systems, domestic and international, that are called into action.

The purpose of this introduction and the volume as a whole is to overcome these traditional disciplinary limitations and to set down the foundations for a new field of legal research capable of illuminating the global regulatory process-comparative law and regulation. To begin with, it is helpful to set forth a working definition of regulation. The concept of regulation is used in a variety of ways in the social scientific and legal literatures (Kahn, 1970: 11; Selznick, 1985: 363-64; Black, 2002: 1). Since the purpose of the field of comparative law and regulation is to cover the great variety of jurisdictions that interact in the global regulatory process, the definition proposed here is broad: regulation is a form of governance designed to address complex social, environmental, and economic problems that relies heavily on rules, enforced against market actors, and administrative authorities. This definition recognizes that administrative authorities are pivotal, but not exclusive, institutions in the regulatory process and that regulatory output is fashioned also by other institutions, including legislatures, public prosecutors, courts, and private bodies. The definition employed here also identifies legally binding rules, enforced against market actors, as the typical technique of regulation but acknowledges that standards can be contained in other types of instruments, such as soft law, and that standards can, in some policy areas, be applied against civil society and public actors.

Comparative law and regulation investigates the law that applies to this regulatory function. It covers all the law of the regulatory process, regardless of the branch of law to which it formally belongs, and it includes all jurisdictions in which such law operates, regardless of whether such jurisdictions are classified as national or international. Since the goal of the field of comparative law and regulation is to capture the fundamental elements of the global regulatory process, the focus is more on the institutional and legal building blocks of the many jurisdictions and less on the technical substance of particular policy areas. Comparative policy studies, however, can serve as a device for revealing more general properties of the global regulatory process and, to the extent this is the case, they are also included.

At the same time as comparative law and regulation moves beyond the limitations of the established legal discipline, it is situated in the field of comparative law. That is because comparative law has developed a series of theoretical and analytical tools, albeit in the context of private law, that are particularly apt for understanding the global regulatory process. The discipline of comparative law was born in the era of the globalization of commerce and has been devoted in large part to building the intellectual apparatus necessary to understand commercial transactions that straddle multiple jurisdictions (Zimmermann, 2008). The globalization of regulation shares 
many of the same attributes as the earlier globalization and therefore the lines of theoretical inquiry central to comparative law can serve, after extensive modification, to analyze the regulatory process as it unfolds across the world.

The global regulatory process is characterized by three essential properties: jurisdictional differences and commonalities; legal convergence and divergence over time driven by social and political processes; and the prescription of new law by political and legal operators based on comparison. ${ }^{3}$ To illustrate briefly with the examples of consumer tracking and parabens regulation: Consumer tracking rules and regulatory enforcement in the United States and the Asia-Pacific Economic Cooperation system are fairly similar, and differ considerably from those same rules and regulatory enforcement in the European Union and Argentina. Although the rules and licensing procedures for parabens vary considerably across the world today, in the future they may-or may not-converge. Convergence might be on the relatively permissive American model, because countries seek to attract investment from American firms and are swayed by free market arguments, or it might be on the tougher European model, because countries wish to guarantee access for their corporations to the EU market and are persuaded by the so-called "precautionary principle" (Scott, 2009; Bradford, 2012). And regardless of whether the outcome is convergence or divergence, the legal and political operators engaged in the global regulatory process argue in favor of new law based on comparison. The odds are that privacy advocates will make the case for more public enforcement of consumer-tracking rules in the United States and East Asia based on the example of European data protection authorities. Multinational cosmetics corporations, by contrast, are likely to draw inspiration from the U.S. system of chemicals regulation to oppose licensing for parabens and other chemicals in Latin America.

Within the field of comparative law, there are three lines of inquiry that can, with significant adaptation and development, shed light on each of these key characteristics of the global regulatory process. Classifications serve to describe and chart legal variation globally and are an important tool for understanding the different legal responses generated by common policy problems (David and Brierly, 1978; Zweigert and Kötz, 1998). The causal theory of legal transplants (Watson, 1974), also known as diffusion in the social scientific literature (Dobbin, Simmons, and Garrett, 2007), points to the conditions under which regulatory institutions, principles, and procedures are likely to converge across the multiple jurisdictions involved in the global regulatory process. And the functional method of comparative law, together with the many debates that it has generated, is the prevalent normative theory in the academy for how political and legal operators should compare to prescribe new law (Rabel, [1924] 1967; Zweigert, 1951; David, 1955; Zweigert and Kötz, 1998; Basedow, 2014).

The rest of this chapter proceeds as follows. The next section reviews the existing fields of legal research that have considered aspects of the global regulatory process

3 Throughout this chapter, the terms "prescribe" and "prescription" refer to the normative activity of recommending new domestic laws and international legal instruments. "Prescribe" and "prescription" are not used to refer to the actual enactment of such laws and legal instruments, which may or may not be the consequence of the arguments and recommendations of legal and political operators. 
and explains their shortcomings - comparative administrative law, global administrative law, and comparative socio-legal studies. The chapter then turns to a systematic exposition of the object of study of comparative law and regulation. First, it outlines the elements of law that are compared across the different jurisdictions, both domestic and international, and that are essential to the multiple jurisdictions that contribute to the global regulatory process: the law of rulemaking, regulatory oversight, regulatory enforcement, and judicial review. Secondly, the introduction puts forward the three lines of theorization, drawn from the field of comparative law, that offer the greatest promise for understanding the essential characteristics of the global regulatory process and that are central to the field of comparative law and regulation. In presenting classifications, legal transplants, and the functional method, the chapter develops each area of theoretical investigation for the public law sphere and the novel context of global regulatory governance. It proposes two new classifications: in the first, the categories reflect historical and doctrinal theories of how public law should discipline the regulatory function; in the second, the categories are based on models of legitimate private involvement in public regulation. As explained below, legal transplants in the regulatory domain can be caused by a number of different factors, but one in particular-power-has been neglected in the existing transplant literature. And, in unpacking the functional method of legal prescription, the chapter dwells on what is generally the last stage of the comparative analysis, that is, recommending a new domestic law or international legal instrument based on the "better" law that has been revealed by the comparative survey. This chapter underscores the need for comparative analysis to be explicit as to the normative criteria that are used to identify the law of one jurisdiction as superior to the laws of other jurisdictions, i.e., the "better" law. It also urges researchers to investigate empirically the operation of what, in appearance, is the "better" law, to ascertain that, in actual fact, it meets the normative criteria.

The introduction concludes with a survey of the individual contributions to the volume. The survey shows that even though the authors work in a number of traditional subfields of law, it is possible to construct an intellectually compelling topography of the emerging field of comparative law and regulation. The review of the individual chapters also discusses how they illuminate the theoretical conclusions outlined in the main part of the introduction. Overall, the chapters reveal the practical and scholarly payoffs that come from building a new field of inquiry dedicated to comparative law and regulation.

\section{EXISTING RESEARCH TRADITIONS}

There are three existing fields of legal research that have addressed elements of how regulation operates worldwide: comparative administrative law, global administrative law, and socio-legal studies. Although these research traditions have made significant advances, they also suffer from critical limitations related to their disciplinary foundations. Driving scholarship in each field is a set of assumptions and categories that 
indicate what to study, using which theories and methods. In each case, the assumptions and categories are ill suited to understanding how policy problems such as consumer tracking, parabens, and many others are handled by the global regulatory process.

\section{Comparative Administrative Law}

Comparative administrative law is focused on bureaucratic authority, broadly speaking. The object of comparison is the institution of public administration and the national laws that govern the operation of public administration in different jurisdictions (Goodnow, 1893; Ziller, 1993; Fromont, 2006; Bell, 2008; Rose-Ackerman and Lindseth, 2010). Since the work of administration is, at least to some degree, the functional task of regulating economy and society, comparing the law of administration in different countries can shed light on the multiple legal systems involved in global regulation. But note that the overlap between administration and regulation, together with their respective governing laws, is imperfect to say the least. On the one hand, administrative law, and hence comparative administrative law, is under-inclusive. Depending on the country, the regulatory process can involve a number of public and private bodies outside of public administration: the political branches, which set down the regulatory agenda and which are governed by constitutional law; public prosecutors, who pursue criminal actions for regulatory offenses subject to the rules of criminal procedure; private litigants, who seek compensation for regulatory breaches in the courts under the law of civil procedure; and private regulatory bodies, which undertake self-regulation, and which act under a combination of public and private law (Coglianese and Kagan, 2007).

On the other hand, administrative law, and therefore comparative administrative law too, can be over-inclusive with respect to regulation. In the case of the United States, administration is largely synonymous with regulation because of the early use of regulation to govern the economy, as opposed to state ownership and industrial planning, and because of the federal organization of government, which leaves most responsibility for functions such as land-use planning to state and local government and separate subfields of law (Breyer et al., 2011). But the American experience is unique. In most other jurisdictions, the opposite is the case: the work of administration is only in small part regulation and instead is focused on providing basic services, managing welfare schemes, overseeing land-use planning, and other types of government activities. The functions of public administration can entail a lot besides regulation and therefore administrative law can include rules and principles that are not aimed specifically at the regulatory function but at other types of government activities (Ziller, 1993).

Although the mismatch between administrative law and regulatory law is a handicap for any legal inquiry focused on regulation, even purely domestic regulation, it is especially so in the global context. Comparing administrative law falls into the trap of comparing the proverbial apples and oranges (Dannemann, 2008; Valcke, 2012). At best, comparative administrative law risks being relatively uninformative on how the law governs the regulatory function in different jurisdictions: in some countries, regulation may be handled by legal actors other than administration, such as 
legislators and criminal prosecutors, while in other countries there may be very little regulation at all. At worst, comparative administrative law can be misleading: from the outside, certain principles and procedures of administrative law might be mistaken for the law applicable to the regulatory function when in actual fact they govern only land-use planning, civil service management, or another function of public administration that is more important in the foreign jurisdiction. In sum, it is necessary to develop an object of legal study that is centered on the functional task of regulating, not on the historical and nation-specific contours of public administration, in order to successfully cross borders and understand the regulatory process in the many jurisdictions that today weigh in on global policy problems such as consumer tracking and parabens.

\section{Global Administrative Law}

Global administrative law studies the numerous international administrative bodies that have mushroomed over the past decades (Kingsbury, Krisch, and Stewart, 2005; Cassese, 2016). Broadly speaking, global administrative law is the international counterpart of comparative administrative law: the object of inquiry is administration and the law that applies to administration-just international not national-and the theoretical concern is the authority and legitimacy of administration. By including international legal systems among the jurisdictions that are important to the regulatory process, this book draws on the insights of global administrative law. Scholarship in global administrative law, however, tends to conceptualize the international level as fundamentally different from the national level and to analyze global administrative bodies in isolation or, at most, as vertically situated above national bodies. But, as discussed earlier, the very same regulatory problem can be handled by national systems like the United States and Belgium, international systems like the WTO and the UN Environment Programme, and in-between systems like the European Union. The different jurisdictions interact and, in doing so, generate the global regulatory process. Therefore, to understand this global regulatory process, it is not enough to focus on only one set of actors and law, even though, being international, global administrative bodies might appear to be the most important for understanding the worldwide dimension of regulation. In many regulatory areas, and at many stages of the regulatory process, national jurisdictions are the key players. Even more important, the global regulatory process is the product of complex interaction among jurisdictions-vertical and horizontal-and therefore it is essential to develop a single set of theoretical and methodological tools aimed specifically at that interaction.

\section{Socio-legal Research}

The third line of scholarship to have addressed elements of the global regulatory process is comparative socio-legal research (Kagan and Axelrad, 2000; Kagan, 2001). Studies in this tradition generally focus on a specific type of regulatory objective, such as safe nursing homes or clean water, investigate empirically how these objectives are achieved in different national legal systems, and, depending on the study, assess 
whether some systems are more effective than others (Vogel, 1986; Braithwaite and Braithwaite, 1995). This research is legal realist and, as such, serves as an essential complement to the largely doctrinal research conducted by legal scholars. Nevertheless, the empirical questions and theories that guide socio-legal research are quite narrow. Since the central concern is how law impacts society, comparative studies in this tradition generally investigate specific types of regulatory policy with direct consequences for social and economic outcomes-health regulations, environmental regulations, and so on-and the enforcement of that policy by state officials (Hutter, 1988; May and Winter, 2000; May, 2003). Yet the global regulatory process encompasses many other types of law and institutional actors: the basic legal framework that guides how regulation is made and enforced, from start to finish, and the public and private actors responsible not only for enforcing, but also for making, overseeing, and adjudicating regulation. In other words, it is necessary to develop an empirically sensitive research agenda that takes a broader view of the law that matters in the global regulatory process. To return to the parabens example, it is important to analyze and assess not simply the policy output of parabens regulation but the legal and political process that gave rise to, and that drives the operation of, that parabens regulation.

\section{ESTABLISHING THE FIELD}

There are two steps to outlining the field of comparative law and regulation. The first is to set down systematically the law, throughout the world, that is the object of study. The second is to sketch the theories and methods that are most promising for understanding the global regulatory process and how the multiple jurisdictions, domestic and international, interact to generate the global regulatory process.

\section{What Law?}

The field of comparative law and regulation investigates the law that applies to the regulatory function, in whatever jurisdiction that function is undertaken. The regulatory function and the applicable law, that is, the regulatory process, are conceived sequentially: making the rules, overseeing and revising the rules, enforcing the rules, and reviewing the rules in court. At each phase, certain actors and certain areas of law, as defined by the traditional legal discipline, play a more prominent role. When rules are made, legislatures and administrative agencies, operating under constitutional and administrative law, are important. Oversight is carried out by public authorities acting largely under administrative law and, less often, constitutional law. Enforcement is conducted by administrative agencies and courts, at the behest of either public prosecutors or private class actions, and, depending on the type of enforcement, triggers the principles of administrative law and criminal and civil procedure. Judicial review is handled by the courts and is guided by constitutional and administrative law. Private bodies can be allowed to exercise one or more of these 

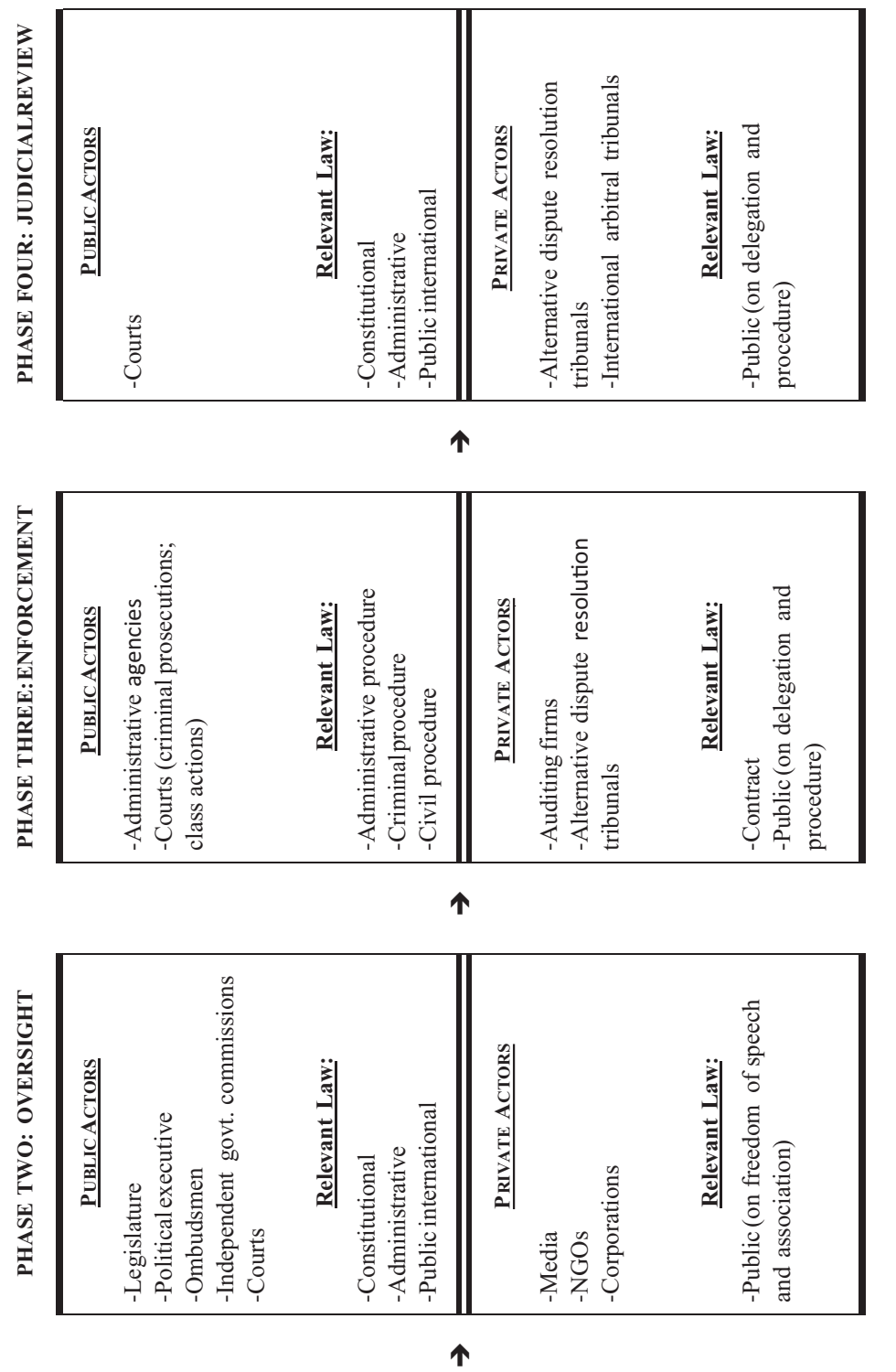

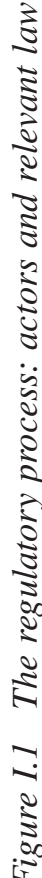

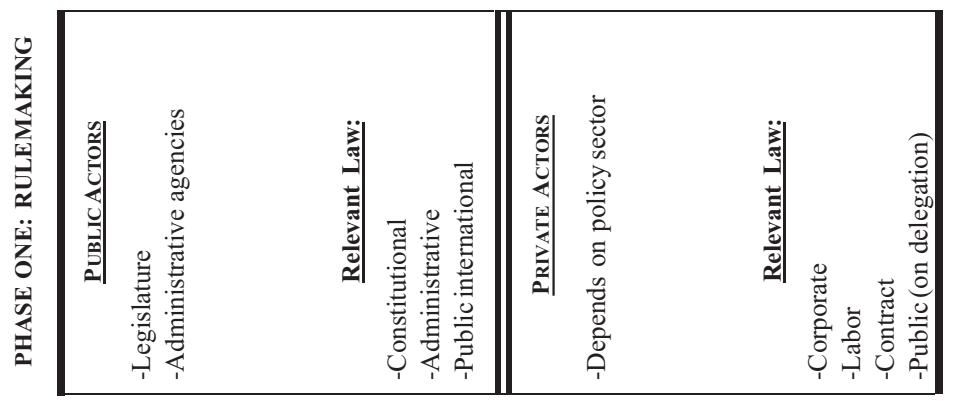


regulatory powers and, in doing so, they are governed by corporate law, labor law, and contract law, as well as public law on permissible delegations and freedom of association and speech. To illustrate with an example well known to lawyers, the rules of conduct for the profession can be developed by private bar associations, overseen by the media and private watchdog organizations, enforced by disgruntled clients in a dispute resolution process managed by the bar, and reviewed, at least in the first instance, in the course of the dispute resolution process. Although the primary focus of the field is regulatory institutions, principles, and procedures, comparative studies of specific regulatory policies - the details of when consumer tracking data can be sold, what chemicals are contained in cosmetics, and so on-can reveal more general properties of the regulatory process and therefore are included to the extent that they serve those purposes. The terminology employed in this discussion reflects the categories that have been developed in domestic law, not the vocabulary typically used in international law. The reader, however, should keep in mind that this exposition of regulatory law is intended to apply to both domestic and international jurisdictions.

Figure I.1 sets out the components of the regulatory process and the corresponding law included in the field of comparative law and regulation. It should be kept in mind that even though the flow chart format is a useful heuristic, the order of the regulatory phases is not set in stone and sometimes they can occur in a different sequence.

Table I.1 below summarizes the coverage of regulatory law and jurisdictions provided by the contributions to this volume. For each stage in the regulatory process, it indicates the precise type of law and the specific jurisdictions analyzed in the individual contributions. For purposes of clarity, the volume follows a classic tripartite scheme that moves from the most traditional form of regulation-by state authorities at the domestic level - to forms that are considered relatively novel-private regulation (at both the domestic and international levels) and international jurisdictions. It is important to note that the European Union defies easy classification and, for some purposes, is treated as a domestic jurisdiction and, for others, as an international jurisdiction. The EU's variable status is a reflection of the uneven character of European integration: at the rulemaking stage, in many policy areas, the EU exercises the power of a domestic jurisdiction, but at the enforcement stage, the EU generally only has supervisory powers, and authority continues to rest primarily with the member states.

Before proceeding any further, it is important to underscore one point which might not emerge clearly enough from this exposition of the regulatory process. For most lawyers trained in the law of a particular jurisdiction, the default position is that the regulatory process occurs, from start to finish, within that jurisdiction. But this assumption no longer holds in the face of globalization. It is not just that there are parallel regulatory processes on common problems such as consumer tracking and parabens that are occurring simultaneously in different jurisdictions throughout the world. Rather, in some cases, before a specific set of rules can take effect, multiple jurisdictions can be called into action. The most obvious jurisdictional configuration is the vertical relationship between international regimes and participating states. Domestic rules are often subject to regulatory oversight and judicial review by international regimes. For instance, an EU rule on parabens must be notified to a WTO oversight committee ${ }^{4}$ and can potentially trigger judicial review in the WTO Dispute 
Table I.1 Coverage of regulatory law chapter by chapter

\begin{tabular}{|c|c|c|c|c|}
\hline & RULEMAKING & OVERSIGHT & ENFORCEMENT & $\begin{array}{l}\text { JUDICIAL } \\
\text { REVIEW }\end{array}$ \\
\hline $\begin{array}{l}\text { Domestic } \\
\text { jurisdictions } \\
\text { (Parts II through } \\
\text { V) }\end{array}$ & $\begin{array}{l}\text { (Part II) } \\
\text { Wagner (public } \\
\text { participation-U.S.) } \\
\text { Smismans (public } \\
\text { participation-EU) }\end{array}$ & $\begin{array}{l}\text { (Part III) } \\
\text { Wiener and Ribeiro } \\
\text { (impact } \\
\text { assessment- } \\
\text { multiple } \\
\text { jurisdictions) } \\
\text { Worthy (freedom of } \\
\text { information-UK } \\
\text { and India) }\end{array}$ & $\begin{array}{l}\text { (Part IV) } \\
\text { Van Rooij } \\
\text { (criminal and } \\
\text { administrative } \\
\text { enforcement- } \\
\text { China) } \\
\text { Hensler (private } \\
\text { class } \\
\text { actions-multiple } \\
\text { jurisdictions) }\end{array}$ & $\begin{array}{l}\text { (Part V) } \\
\text { Bignami (general } \\
\text { principles-U.S. and } \\
\text { Europe) } \\
\text { Huang and Law } \\
\text { (proportionality- } \\
\text { South Korea, Japan, } \\
\text { Taiwan, China) } \\
\text { Lamprea, Forman, } \\
\text { and Chapman (right } \\
\text { to health-Colombia) } \\
\text { Rose-Ackerman, } \\
\text { Egidy, and Fowkes } \\
\text { (procedural } \\
\text { principles-U.S., EU, } \\
\text { Germany, South } \\
\text { Africa) }\end{array}$ \\
\hline $\begin{array}{l}\text { Private } \\
\text { regulation } \\
\text { (domestic/ } \\
\text { international) } \\
\text { (Part VI) }\end{array}$ & $\begin{array}{l}\text { Strauss (industry } \\
\text { standard } \\
\text { setting-U.S. and } \\
\text { EU) } \\
\text { Coglianese } \\
\text { (performance-based } \\
\text { regulation-U.S.) }\end{array}$ & $\begin{array}{l}\text { Worthy (freedom of } \\
\text { information-UK } \\
\text { and India) }{ }^{a}\end{array}$ & $\begin{array}{l}\text { Short (corporate } \\
\text { codes of } \\
\text { conduct-multiple } \\
\text { jurisdictions) }\end{array}$ & $\begin{array}{l}\text { Yackee }(\text { international } \\
\text { investment law) }\end{array}$ \\
\hline $\begin{array}{l}\text { International } \\
\text { jurisdictions } \\
\text { (Part VII) }\end{array}$ & $\begin{array}{l}\text { Zaring } \\
\text { (international } \\
\text { financial networks) }\end{array}$ & 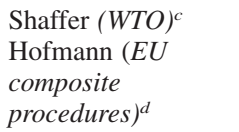 & $\begin{array}{l}\text { Hofmann }(E U \\
\text { composite } \\
\text { procedures })^{d}\end{array}$ & $\begin{array}{l}\text { Shaffer }(\text { WTO })^{c} \\
\text { Yackee }(\text { international } \\
\text { investment law) }\end{array}$ \\
\hline
\end{tabular}

Note: The chapters in Part I analyze the historical development of the regulatory state.

${ }^{a}$ Worthy's contribution (included in Part III) discusses both the public and the private dimension of oversight.

${ }^{b}$ Yackee's contribution (included in Part VII) analyzes international arbitral tribunals, which are a form of private international regulation.

${ }^{c}$ Shaffer covers the WTO committee system, which is an example of oversight, as well as the WTO dispute resolution system, which is a form of judicial review.

${ }^{d}$ The EU composite procedures covered by Hofmann serve the purposes of both regulatory oversight and regulatory enforcement.

Settlement Body (Shaffer, this volume). Intervention in the domestic regulatory process can even be horizontal, from another domestic jurisdiction. For example, a privacy rule issued by the U.S. Federal Trade Commission that limits consumer tracking is subject to an adequacy determination in the EU, which entails both regulatory oversight by the privacy authority and, possibly, judicial review in the Court of Justice of the EU. ${ }^{5}$ In

4 World Trade Organization, Committee on Technical Barriers to Trade, Notification, G/TBT/N/EU/157 (Oct. 1, 2013).

5 Article 29 Data Protection Working Party, Opinion 4/2000 on the level of protection provided by the "Safe Harbor Principles" (May 16, 2000); Commission Decision 520/2000/EC, 2000 O.J. (L 215) 7 (EC); Case C-362/14, Schrems v. Data Protection Commissioner, 2013 WL 
sum, to navigate the contemporary, global, regulatory process, it is vital to know the law of multiple jurisdictions and to appreciate that, at any point in the regulatory process, those laws may intersect.

To better understand the scope and the nature of the law covered by the field of comparative law and regulation, it is necessary to provide some historical context. Like constitutional and administrative law and their comparative counterparts, the emergence of the field of comparative law and regulation is linked to a concrete set of political and social developments. Regulation, like written constitutions and public administration, is a distinct type of historical and social phenomenon that is not universal to all human societies. With the exception of the United States, regulation has become a pervasive form of state governance only in the past thirty years (Levi-Faur, 2005; Scott, 2006; Dubash and Morgan, 2012). The rise of regulation is directly tied to the extensive privatization and liberalization of markets that occurred in many countries beginning in the 1980s (Suleiman and Waterbury, 1990; Thatcher, 2007). Before, government intervention in the economy was direct-through state ownership of market sectors and extensive industrial planning. Since then, even though countries still seek to accomplish many of the same fundamental policy objectives, they do so by governing private markets actors with rules (Majone, 1994; S. Vogel, 1996; Levi-Faur and Gilad, 2004; Kelemen, this volume; Shaffer, this volume). Rules are now necessary both to create and maintain competitive markets and to further a variety of social, environmental, and redistributive policies that can no longer be achieved by directly managing the economy. The regulatory technique also has tended to favor a certain type of government institution: the specialized administrative authority with the knowledge and resources necessary to regulate a particular market sector and regulatory problem (Kelemen, this volume; Shaffer, this volume). As is underscored by this exposition of the regulatory function and the relevant law, summarized in Figure I.1, administrative agencies are pivotal: they engage in both rulemaking and rule enforcement and, as a result, they are the prime target of both oversight and judicial review.

The emergence of the field of comparative law and regulation has been driven not only by the rise of a common mode of governance for achieving policy objectivesregulation-but also by the diffusion of a certain type of legal system-liberal democracy (Huntington, 1991; Simmons, Dobbin, and Garrett, 2008). This definition of the regulatory process, and what law can be analyzed as belonging to that regulatory process regardless of the jurisdiction, is as much a product of the instrumental activity of regulating as it is of the regime type of liberal democracy. Even the simple division of labor between making rules and enforcing rules, which might seem necessary to an area of human activity like governing markets, is the product of a distinctive, liberal order that insists that first rules be made and publicized and that only then can citizens be subject to enforcement action by their governments (MacCormick, 1999: 115). The oversight and judicial review components of the regulatory process illustrate even more clearly how this conceptualization of an object of legal study that can cross national borders and domestic law books is tied to a certain form of government which, with the diffusion of liberal democracy, has become more prevalent today: the checks and

614CJ0362 (Oct. 6, 2015). For these purposes, the EU operates as a domestic jurisdiction since it has no international law claim of authority over the U.S. 
balances afforded by external oversight and judicial review are, by definition, irrelevant to an autocratic regime but essential to a liberal one (Mannori and Sordi, 2001).

This logic of liberal democracy is all the more true of the specific types of regulatory law included in this volume under each stage of the regulatory process. The legal procedures by which the public participates in rulemaking are generally enacted to further the public accountability important in liberal democracies. So too for laws guaranteeing citizens access to government documents and requiring that regulation take into account environmental and economic impacts. The criminal and civil procedure analyzed in this volume is assessed based on both the effective implementation of regulatory policy and the respect for liberal rights. The section on judicial review analyzes principles-proportionality, the right to health, and participation rights - that are meaningful within the broader context of liberal democracy.

In sum, the field of comparative law and regulation and the assessment of what law to cover are built on the historical trend, experienced across many parts of the world, toward regulating in line with liberal democratic principles of public law. That is a far cry from saying that the regulatory process across the globe is identical and indeed, as described below, one of the essential ambitions of the field is to capture the extensive variation that separates jurisdictions. Not all jurisdictions will have all types of regulatory law and even if they do, it may very well operate in quite different ways. This intellectual framework can even encompass authoritarian regimes: many jurisdictions that are considered authoritarian have law to compare on certain elements of the regulatory process and, in those cases in which there is no law to be found, the silence can also be instructive. In other words, it is important to be mindful of the historical origins of the categories and assumptions that serve to organize the field but, at the same time, it is vital to include as many jurisdictions as possible in the comparative projects of the field.

To conclude this section, it bears pointing out what is not covered by comparative law and regulation. Although the definition of the regulatory function and the applicable law might appear so capacious as to include all law, there are plenty of areas that are excluded because they are too far removed from the regulatory function. This is true for the substantive principles of private law and criminal law. In both contexts, background principles on what type of actions can give rise to civil liability or criminal punishment can sometimes limit the scope of regulatory enforcement. Because those principles, however, are driven by more general considerations related to duties of care and culpability, and not by the regulatory schemes enacted to address particular economic and social problems, they are peripheral to the main object of inquiry. The constitutional law that governs elections and other aspects of what might broadly be called the law of democracy is also excluded. Even though elections, political parties, and general parliamentary procedure undoubtedly influence regulation, they, together with their legal framework, are too far removed from the process of enacting specific regulatory norms to be considered part of law and regulation. Last, as was explained earlier, there are subjects such as land-use planning and civil service law that in many legal systems are central to the field of administrative law but are not covered by comparative law and regulation. 


\section{Which Questions, Theories, and Analytical Tools?}

The field of comparative law and regulation is motivated by the larger intellectual project of understanding the global regulatory process. How are social and economic problems like consumer tracking and parabens handled in the contemporary, global, regulatory process? The objective is not to generate a laundry list of regulatory law across the dozens of national and international jurisdictions involved in that process. Rather, the field seeks to develop theories and analytical tools that illuminate the essential properties of the global regulatory process-jurisdictional diversity and commonality, including both domestic and international jurisdictions, convergence or divergence over time, and prescription based on comparison. What are the distinctive public institutions, procedures, and principles that mark different jurisdictions and that can give rise to variation in the treatment of common regulatory problems across the globe? What are the political and social processes that cause convergence in some jurisdictions, with respect to certain types of policy problems and regulatory law? How should comparative arguments in favor of law reform, a favorite rhetorical device in the global regulatory process, be assessed and improved?

The more general field of comparative law offers a good point of departure for addressing these questions. The field emerged in the twentieth century in the context of the globalization of commerce and has been dedicated, to a significant extent, to the project of facilitating commercial transactions across different jurisdictions (Dubinsky, 2005: 219-20; Zimmermann, 2008). Many of the theoretical and methodological debates of the discipline have been driven by the need for the law of contracts, essential to global transactions, to straddle multiple jurisdictions. Traditional comparative law, therefore, serves as a useful springboard for understanding globalization, this time not in the private law sphere but in the different context of public law, that is, the global regulatory process. Comparative law has developed three promising lines of theoretical inquiry for understanding the defining features of the global regulatory process: descriptive classifications, causal transplant theory, and normative theory on how to compare in the service of law reform and law unification, including the functional method. Classification schemes serve to capture the important legal attributes that characterize jurisdictions and to understand differences and similarities among jurisdictions. Theories of legal transplants are designed to explain whether or not law spreads and jurisdictions converge. And the functional method provides a solid basis for evaluating and improving the comparative arguments used by regulatory operators to recommend new law.

Differences and commonalities: paradigms of public law and public-private relations One of the classic ambitions of comparative law is to describe and analyze deep-seated differences and similarities in legal systems across the world (Reimann, 2002; Glenn, 2008, 2011; Pargendler, 2012). To this end, classifications have served as an important intellectual tool. They cut through the inevitable morass of details and legal instruments that are required for the day-to-day operation of the law in any particular system and identify the crucial elements that generate the law across multiple jurisdictions. The categories that constitute a classification are designed to capture complex patterns of 
behavior in the law and to convey the multiple, interrelated characteristics that separate some jurisdictions and unite others. The categories serve to understand how, in some cases, similar disputes and problems can trigger different legal processes and, in certain instances, culminate in different outcomes. Because they operate as a tool for understanding variation, classifications are the key to mapping legal systems worldwide. They provide legal actors with the intellectual resources necessary to navigate legal systems outside their home jurisdiction and to interact with the multiple jurisdictions that decide their legal problems.

Although description and mapping based on classifications is a major area of academic endeavor in comparative law, it has also generated significant criticism within the discipline (Riles, 1999; Glenn, 2008). Classifications and their categories inevitably simplify legal systems; indeed that is one of their great virtues. But with simplification comes intellectual risk: that the categories fail to capture the crucial elements of legal systems, that the categories only work for some systems, that certain jurisdictions are misclassified, or that it is impossible to tell whether one, or indeed any, jurisdiction should be classified as belonging to one or the other category. At the same time, classifications tend to be static. That is, once a jurisdiction is classified, there is intellectual resistance to admitting that what, by definition, are the fundamental elements of the jurisdiction have changed, and that it is necessary to switch the classification and redraw the map. Although these undoubtedly are valid concerns that must be taken into account in developing legal classifications, the conceptual exercise remains an important one. As long as the classification scheme does not claim to be exclusive or definitive, it can offer a valuable heuristic to political actors and legal scholars.

As explained earlier, traditional comparative law is mainly preoccupied with private law. Thus it should come as no surprise that the principal classification in the field applies to the legal sources and courts that are responsible for deciding private law disputes - the civil law tradition versus the common law tradition (David and Brierly, 1978; Merryman, 1985; Zweigert and Kötz, 1998). ${ }^{6}$ In addition, a couple of classifications have been developed to capture differences and similarities in how legal systems organize and resolve criminal cases between private citizens and public prosecutors: the adversarial versus inquisitorial models of criminal procedure (Langer, 2014); and the hierarchical versus coordinate forms of authority for civil and criminal procedure (Damaška, 1986). In constitutional law, there are classifications built on categories such as systems of judicial review (Ferreres Comella, 2011; Stone Sweet, 2012), the structure of government (Halberstam, 2012), and constitutional amendment rules (Albert, 2014). In administrative law, one source of variation has classically been traced

6 Although the terms "civil law tradition" and "common law tradition" are often used in the more general literature to refer both to private and criminal law, the best-known theoretical and historical elaborations of these categories refer almost exclusively to the system for deciding private law disputes in different jurisdictions. The private law emphasis can also be seen in the use of the classification in the recent empirical literature on the effects of legal tradition on economic and social outcomes, known as the legal origins project. The project codes systems as common law or civil law based on whether it uses judicial precedent or a code as the source of law for deciding commercial disputes (Djankov et al., 2002: Table 1, Description of the Variables; La Porta et al., 1999: 231). 
between systems: adjudication of disputes between individuals and administration by a tribunal connected to the executive branch in the droit administratif and by the ordinary courts of law in the common law (Dicey, 1885; Bignami, this volume).

Drawing on the methodological debates of comparative law on how to construct classifications, it is possible to isolate two important sources of similarity and difference in the regulatory domain, across both domestic and international jurisdictions. The first relates to the paradigms of public law that discipline the regulatory process and the second to the permissible forms of private involvement in public action. Not only do these classifications provide intellectual tools for understanding the variation that marks the global regulatory process, but they also can advance knowledge in the more general discipline of comparative law. The familiar classifications mentioned earlier presume fairly rigid distinctions between the operation of law in the private and public spheres and in the various domains of public law. A classification scheme for an area like law and regulation, however, must deploy categories that cut across a number of subfields of law. To the extent that this is possible, it suggests that the general discipline has ignored important social, political, and intellectual forces that, like the activity of regulating, fail to respect the conventional boundaries of the law but nonetheless have had significant consequences for how the law permits markets and society to be regulated. Likewise, in contrast with the traditional discipline, comparative law and regulation includes both the domestic and the international spheres and seeks to develop a theoretical apparatus, including classifications, that encompasses both. The classifications advanced below suggest that, at least in this area of law, the social and legal processes of globalization have advanced to the point where it is no longer intellectually coherent to splinter theoretical investigation between the domestic and international spheres and that traditional comparative law should seek to incorporate international jurisdictions too.

The following discussion explains each classification scheme in turn, illustrating each category in the classification with specific jurisdictions. It identifies the different elements of law and regulation-rulemaking, oversight, enforcement, and judicial review-associated with the categories and discusses the historical and intellectual origins of the categories. Mindful of the critique of classifications in the more general discipline, the argument is not that all legal systems can be classified as belonging exclusively to one or the other category or that jurisdictions remain set in stone over time. The claim is, rather, that even though jurisdictions can possess a variety of legal currents, some will predominate, and therefore it is often possible to come to plausible conclusions as to how to classify the legal system. In other words, even though the classifications can and should be contested in particular cases, they remain a valuable heuristic for understanding variation in the global regulatory process.

Paradigms of public law Today there are at least four different paradigms of what is protected by the public law that applies to the regulatory function: rule by law, fundamental rights, ballot-box democracy, and transformative democracy. Although these paradigms are most apparent in what courts do and the judicial review of regulation, they also shape regulatory oversight and regulatory enforcement.

Rule by law refers to the classic theory that all state action must be authorized by a written law and must adhere to the parameters of that law (Allison, 2007: 157-85; 
Krygier, 2012, 2015). ${ }^{7}$ This paradigm emphasizes that legal certainty, rules, and independent policing of the rules by courts are central to the legitimacy of public action. The origins and substance of the law are somewhat secondary to the fact that the state and the bureaucracy are made subject to the law. Historically, rule by law is associated with the rise of liberalism, the emergence of a private sphere separate from the state and in need of protection from the state, and the administrative law of the nineteenth century (Mannori and Sordi, 2001; Bignami, this volume). It is evident in classic common law and continental doctrines of judicial review such as reviewing administrative acts for being ultra vires or in excess of power (Bignami, 2011b: 899).

Although, today, rule by law has been joined in western democracies by other types of public law, it operates as the primary form of judicial oversight in certain newer or transitional democracies and even in certain authoritarian systems. It is associated with a strong executive and a relatively weak legislature and judicial system, either because of the authoritarian power structure or because of a strong civil service and a historical legacy of one-party dominance. The latter is the case for the East Asian countries of Japan and, until very recently, Taiwan and South Korea (Huang and Law, this volume; Ohnesorge, this volume). In those legal systems, much of the emphasis of administrative law reform has been to strengthen the judiciary, so as to ensure that courts will truly be in a position to hold the state to the law, but the substance of judicial review remains focused on whether state action is authorized by the law and falls, roughly speaking, within the parameters contemplated by the law (Huang and Law, this volume; Ohnesorge, this volume).

The rule-by-law paradigm also has traction for understanding developments in authoritarian systems like China and Egypt (Ginsburg and Moustafa, 2008). While in the classic formulation, rule by law is designed to protect an autonomous private sphere from incursions by an arbitrary state, in the theories that have been used to understand courts in authoritarian systems, rule by law can serve as a tool through which an authoritarian party can seek to establish control over a wayward bureaucracy. That bureaucracy cannot be controlled through hierarchical organization linking the bureaucracy to the authoritarian party because of the complexities of modern economic policymaking or because of entrenched cronyism and corruption. In these political science theories, judicial review of administrative action based on the authorizing law can serve as a substitute for hierarchical control (Moustafa, 2007; Ginsburg, 2008). In such systems, judicial review can also be used to generate the legal certainty necessary to attract foreign investment (Moustafa, 2007).

In jurisdictions spurred by the rule-by-law paradigm, other types of judicial review of regulation such as proportionality are either absent or relatively inactive. Regulatory oversight mechanisms that are designed to guarantee public accountability and fundamental rights, such as freedom of information rights and independent ombudsmen, are rare or under-utilized (Carmona, 2011; Jianwei, 2012; Xiao, 2012; Chinese Human Rights Defenders, 2014). Regulatory enforcement is, at least in theory, driven by the importance of legal certainty and the need to demonstrate that the law is not arbitrary

7 Although "rule by law" is also used by Tom Ginsburg and Tamir Moustafa in their book on law in authoritarian regimes (2008), the term is defined here more broadly and includes some of the core elements of "rule of law" in contemporary western democracies. 
but is enforced equally against all private actors (Vande Walle, 2013: 127-44; van Rooij, this volume). The initiative rests largely in the hands of public actors, that is, criminal prosecutors and administrative authorities, as opposed to private class actions, and it can be used symbolically to underscore the application of law to all (van Rooij, this volume).

In the fundamental rights model, which is characteristic of many European democracies, the role of law in the regulatory process goes beyond enforcing rule by law. It is designed to ensure that the state actors involved in the regulatory process-the legislature and the political executive as well as state administration and the various bodies responsible for implementation-respect a variety of liberal rights and, to a lesser extent, certain positive social and economic rights (Bignami, this volume). The fundamental rights paradigm is the historical product of a strong bureaucracy and a centrally organized state, powerful courts, and a somewhat cautious approach to electoral politics and the legislative branch in the wake of the inter-war experience with mass democracy and dictatorship.

The fundamental rights paradigm is reflected in doctrines of judicial review of regulation, which emphasize economic and social rights and proportionality balancing to set limits on state interference with those rights (Bignami, 2011b: 899-900; Bignami, this volume; Rose-Ackerman, this volume). It is also apparent in a distinct type of oversight mechanism that has mushroomed since the 1980s: independent ombudsmen and government commissions with the mission of safeguarding specific fundamental rights in the activities of the state, including regulation (de Beco, 2009; European Union Agency for Fundamental Rights, 2010; Bignami, 2011a). Consistent with the historical tradition of strong bureaucracy and distrust of democratic populism, regulatory enforcement is triggered largely by state actors, albeit with a much greater emphasis on safeguarding rights than in rule-by-law jurisdictions. In legal systems such as the United Kingdom and Scandinavian countries, which historically have experienced greater democratic stability, the emphasis on fundamental rights, especially as enforced by formalist courts, has traditionally been less significant. With the Europeanization of public law, however, that difference is fading. In the international sphere, with respect to a limited set of economic rights and judicial review, the WTO appears to be adopting the fundamental rights model. The WTO agreements establish a number of free trade rights but, at the same time, recognize that national regulation in furtherance of public policy goals is legitimate. The Dispute Resolution Body, which has been tasked with adjudicating challenges to national regulation based on the rights set down in the WTO agreements, has developed a doctrinal approach akin to proportionality that balances public purposes against free trade rights (Shaffer, this volume).

In the ballot-box democracy paradigm, the public law that disciplines the regulatory process is designed to promote democratic proceduralism (Bignami, this volume). In legal theory, the legitimacy of state action pivots on the democratic process and the directly elected branches of government: all state action is to be controlled by the legislative assembly and the political executive, and the bureaucracy is required to follow procedures that promote popular participation in policymaking. This model is associated with a weak central bureaucracy and executive branch, strong courts, and a stable and long tradition of elections and legislatures. The United States, which is the prime example of ballot-box democracy, is characterized by an outsized influence of 
the courts and the adversarial, common law model of government administration. The courts are tasked with functions that are handled, elsewhere, by administrative authorities; when powers are delegated to administrative agencies, their procedure is adversarial and judicial review is all but certain (Kagan, 2001; Morag-Levine, 2003; Schiller, this volume). The proceduralism of the common law state was, after the demise of substantive due process and economic and social rights in the New Deal, coupled with a vision of public law as a handmaiden of the electoral process and democracy (Bickel, 1962; Ely, 1980). In other words, in the face of the contemporary state function of regulating complex social and economic problems and the contemporary state actor of bureaucracy, the ambition of public law is to safeguard the original, constitutional model of ballot-box democracy.

American ballot-box democracy is reflected in the doctrines employed in the judicial review of administrative rulemaking, which are highly procedural in nature and are justified, in legal theory, as a means of ensuring that the administrative state replicates the pluralism of the democratic process (Bignami, this volume; Rose-Ackerman, this volume; Wagner, this volume). In the regulatory sphere, the best known of these doctrines is arbitrary and capricious review of administrative rulemaking, what has become known as "hard-look review" or, more broadly speaking, "proceduralized rationality review" (Mashaw, 2012: 289). The corollary of democratic proceduralism is relatively little judicial review designed to safeguard substantive values independent of the statutory framework. The importance of ballot-box democracy has also undermined the emergence of oversight mechanisms outside of the tripartite scheme of government, that is, independent ombudsmen and government commissions tasked with enforcing rights (Grunewald, 1988: 53-55; Bignami, 2007: 696-97). In the domain of regulatory enforcement, the prominence of private class actions as compared with criminal prosecutions and administrative enforcement is a reflection of the ballot-box model: the class action is a historical import from the English common law which has been far more successful in America than in England due to a weak state, strong courts, and democratic populism (Hensler, this volume).

In the transformative democracy paradigm, the law is conceived not as a way of overseeing regulatory institutions, including bureaucracies and the political branches, but as a means of supplanting and profoundly transforming those institutions. This paradigm is evident in a number of new democracies with a history of a weak or corrupt state, which in many cases also encompasses the traditional judiciary, and a feeble democratic process (Saiegh, 2010; Zuvanic and Iacoviello, 2010; Francheschet and Díez, 2012). Examples include India and a number of countries in Latin America.

Transformative democracy captures a wide swath of law and regulation. The courts responsible for judicial review are often new, as in the case of newly established constitutional courts, or newly invigorated, as where access to justice has been dramatically expanded for individual litigants (Smulovitz, 2012). They enforce a wide range of positive rights - more extensive than in the fundamental rights model-based on the visions of substantive equality and distributive justice contained in their constitutions (Gargarella, 2006; Gauri and Brinks, 2008; Lamprea, Forman, and Chapman, this volume). Although written constitutions in transformative democracies tend to list a more comprehensive set of individual rights than in established democracies, courts are motivated as much by the constitutional text as by the need to 
act in the face of weak bureaucracies and low state capacity (Lamprea, Forman, and Chapman, this volume). Common oversight mechanisms, such as transparency, which in other democracies are conceived largely as a supplement to the ordinary political process, are used for purposes of subverting and transforming both the bureaucracy and the traditional system of political competition (Worthy, this volume). These jurisdictions are relatively open to establishing alternative forms of regulatory enforcement that rely on private initiative (Gidi, 2003; 2012: 901-39) and additional, non-traditional oversight mechanisms, such as independent rights and accountability bodies (Ackerman, 2010; Reif, 2011).

Table I. 2 summarizes the categories of public law and how they shape judicial review and other elements of regulatory law.

Models of public-private relations A second major form of variation that separates legal systems and that can illuminate jurisdictional diversity and similarity in the global regulatory process concerns the legal relationship between public and private actors (Bignami, 2011b: 884-90). The differences affect primarily the law that applies to rulemaking, whether by government authorities or by private bodies, but they also shape regulatory enforcement.

By definition, regulation acts upon private markets to achieve economic, environmental, health, and other public ends. The interests of a host of market and civil society actors are directly affected and the regulatory process in most places is designed to

\section{Table I.2 Paradigms of public law}

\begin{tabular}{|c|c|c|c|c|}
\hline & Rule by law & $\begin{array}{c}\text { Fundamental } \\
\text { rights }\end{array}$ & $\begin{array}{l}\text { Ballot-box } \\
\text { democracy }\end{array}$ & $\begin{array}{c}\text { Transformative } \\
\text { democracy }\end{array}$ \\
\hline Theory & $\begin{array}{c}\text { State action pursuant } \\
\text { to law }\end{array}$ & $\begin{array}{l}\text { State action in } \\
\text { accordance with } \\
\text { fundamental rights }\end{array}$ & $\begin{array}{c}\text { Procedural } \\
\text { democracy in all } \\
\text { state action }\end{array}$ & $\begin{array}{c}\text { State action } \\
\text { transformed by law } \\
\text { and rights }\end{array}$ \\
\hline Political context & $\begin{array}{c}\text { Strong executive, } \\
\text { weak legislature and } \\
\text { courts }\end{array}$ & $\begin{array}{l}\text { Strong executive } \\
\text { and courts, } \\
\text { distrust of } \\
\text { democratic } \\
\text { populism }\end{array}$ & $\begin{array}{l}\text { Weak executive, } \\
\text { strong courts and } \\
\text { legislature }\end{array}$ & $\begin{array}{c}\text { Weak state } \\
\text { (bureaucracy and } \\
\text { traditional } \\
\text { judiciary), weak } \\
\text { democratic process }\end{array}$ \\
\hline $\begin{array}{l}\text { Doctrines of } \\
\text { judicial review }\end{array}$ & $\begin{array}{l}\text { Authorized by and } \\
\text { within the scope of } \\
\text { law }\end{array}$ & $\begin{array}{l}\text { Rights and } \\
\text { proportionality } \\
\text { test }\end{array}$ & $\begin{array}{c}\text { "Proceduralized } \\
\text { rationality review," } \\
\text { i.e., "hard-look } \\
\text { review" }\end{array}$ & $\begin{array}{l}\text { Positive rights (civil } \\
\text { and political, social } \\
\text { and economic) }\end{array}$ \\
\hline $\begin{array}{l}\text { Oversight } \\
\text { mechanisms }\end{array}$ & Relatively few & $\begin{array}{l}\text { Independent rights } \\
\text { bodies }\end{array}$ & $\begin{array}{l}\text { Classic tripartite } \\
\text { scheme }\end{array}$ & $\begin{array}{l}\text { Independent rights } \\
\text { and accountability } \\
\text { bodies }\end{array}$ \\
\hline $\begin{array}{l}\text { Regulatory } \\
\text { enforcement }\end{array}$ & Public initiative & $\begin{array}{l}\text { Mostly public, } \\
\text { some private } \\
\text { initiative }\end{array}$ & $\begin{array}{l}\text { Public and private } \\
\text { initiative (class } \\
\text { actions) }\end{array}$ & $\begin{array}{l}\text { Public and private } \\
\text { initiative (class } \\
\text { actions) }\end{array}$ \\
\hline Cases & $\begin{array}{c}\text { Japan, South Korea } \\
\text { (Supreme Court), } \\
\text { China }\end{array}$ & $\begin{array}{l}\text { European Union, } \\
\text { European } \\
\text { countries, WTO } \\
\text { dispute resolution } \\
\text { (free trade rights) }\end{array}$ & United States & $\begin{array}{l}\text { Latin American } \\
\text { countries, India }\end{array}$ \\
\hline
\end{tabular}


include and accommodate these private actors. Although the law generally recognizes that private actors play a legitimate role in public regulation, the role that is carved out by the law differs systematically among jurisdictions. In established democracies, there are two major types of public-private relations in regulatory law: pluralism, the paradigmatic case being the United States, and neo-corporatism, classically identified with Europe, in particular northern European systems (Schmitter, 1974; Lijphart, 1999; Bignami, 2011b).

Broadly speaking, the difference between pluralism and neo-corporatism can be summarized as follows. ${ }^{8}$ In pluralist systems, private groups are allowed to compete for influence throughout the regulatory process, whether handled primarily by public or private bodies, but they are not permitted to formally exercise regulatory functions. ${ }^{9}$ In neo-corporatist systems, by contrast, private groups are often given an official role in policymaking, both traditional public regulation and private self-regulation: representatives of interest groups sit on government bodies and private associations take part in state-recognized self-regulatory schemes. This organization of public-private relations is created and sustained by the general principles of public law that reign in pluralist and neo-corporatist systems. In the pluralist United States, constitutional law constructs a fairly categorical divide between the public and private spheres: private groups are not formally allowed to exercise public rulemaking powers (cf. Volokh, 2014) while at the same time public actors are heavily restricted in how they regulate the internal affairs of private groups (Gardbaum, 2003; Nelson, 2015). By contrast, in neocorporatist Europe, the law allows the line between the public and private spheres to be routinely blurred. In constitutional law, this mixing of public and private action has been tested largely in the area of workplace regulation, which allows for private bargains between labor unions and industry associations to supplant state administrative action, and, at the same time, often imposes public requirements on the internal organization of labor and corporate actors. Perhaps the best-known illustration is the German constitutional principle of the "social state" and the public interference with, and empowerment of, private market actors that has been allowed under that principle (Kommers and Miller, 2012: 659-65).

Pluralism and neo-corporatism have been linked to a variety of theories of political philosophy. American pluralism is rooted in the notion that competition among

8 This classification is inspired by political science theories of pluralism and neocorporatism (Adams, 2004). It should be noted that the classic definition in political science turns not only on how interest groups are incorporated in policymaking but also on how they are organized in society: in pluralism, there are numerous, relatively small organizations while in neo-corporatism there are a few, broadly representative interest associations.

9 Political science theories typically focus on the high-level politics of social and economic policymaking (Schmitter, 1974; Lijphart, 1999). In particular, neo-corporatism is associated with the sweeping tripartite bargains between government and the peak associations of labor and industry that were popular in the 1970s and 1980s and that were designed to govern a host of policies related to the workplace, macroeconomic indicators, and the welfare state. Neocorporatist forms of interest representation, however, have never been limited to just labor and business groups or to grand macroeconomic bargains. They extend to government regulation in areas such as healthcare, the environment, and consumer policy, and to the entire sweep of the regulatory process, from rulemaking to enforcement. 
economic and social interests, free of state intervention, results in stable and fair outcomes, and that the primary function of the political process is to serve as a neutral arena for interest group competition (Truman, 1951; Dahl, 1971; Tichenor and Harris, 2005). To single out a particular group or set of groups, as part of a public regulatory scheme, would be to unfairly and unproductively interfere with that competition. Neo-corporatism, by contrast, rests on political theories in which society is conceived as a set of interdependent social and economic, and in some cases, territorial and religious, units (Duguit, 1901; Laski, 1919; Romano, 1946; Hayward, 1960; Gierke, 1977). The duty of the state, which is interconnected with society, is to foster the different groups that constitute society and to ensure balanced representation of those groups in the policymaking activities of the state. The two traditions of public-private relations can be captured with the contrasting metaphors of interest group competition and interconnected social solidarities.

Although the difference between pluralism and neo-corporatism may seem quite abstract, it is both cause and effect of a number of concrete aspects of regulatory law. In American pluralism, when administrative agencies engage in rulemaking, the law guarantees private parties formal equality before the bureaucracy: all private parties have a right to participate in the administrative process, through notice-and-comment rulemaking, and to enforce those rights in the courts (Wagner, this volume). Private, industry bodies also routinely undertake rulemaking functions, but most often in the shadow of the law, in the numerous gaps left open by the formal rules. Private associations, generally speaking, are not officially mentioned and empowered by statute and, in some policy areas, they may actually compete to supply the rules for an industry. At the same time, the internal governance of private bodies is not regulated by the state, even though, in practice, such bodies may not be competitors but monopolists, that is, one powerful industry association sets the terms of social and economic relations in its particular market sector. A good illustration of this private side of pluralist systems is industry standard-setting associations, which are private bodies that make the rules for how products are manufactured but are not singled out in public health and safety regulations nor subject to state requirements on who gets to join and how standards are to be set (Mattli and Büthe, 2003: 23-25; Strauss, this volume). A final element of pluralist law is regulatory enforcement. As mentioned earlier, the United States is remarkable in the extent to which private litigants enforce public regulatory schemes. But American law also stands out in how private actors get into court: if the scheme includes a private right of action, any individual, regardless of history or organizational affiliation, is allowed to bring litigation on behalf of the class of victims as long as that individual can demonstrate to the court that he or she is typical of the class and that the members of the class are similarly situated (Hensler, this volume).

In European neo-corporatism, the blurred line between the private and public spheres is visible in both public and private rulemaking. In public rulemaking, certain market and social actors are often singled out, based on their membership numbers and their type of constituency, to sit on official advisory committees, with the aim of achieving balanced representation of civil society in the policymaking activities of the state. One 
prominent example is the European Union (Smismans, this volume). ${ }^{10}$ The law can also empower specific private bodies to enact self-regulatory rules, while contemporaneously requiring that such private bodies give other social actors the opportunity to participate in their work, hence achieving, at least in theory, the same balanced representation as in public rulemaking. On this self-regulatory dimension of neocorporatism, European standard setting provides an important illustration (Schepel and Falke, 2000; Strauss, this volume). At the international level as well, standard setting follows the neo-corporatist, not the pluralist, model: international trade agreements rely heavily on the work of two monopolist private bodies-the International Organization for Standardization and the International Electrotechnical Commission-and the two organizations are legally designed to achieve balanced territorial representation of industry groups, and to a lesser extent other societal groups (Büthe and Mattli, 2011). To conclude with regulatory enforcement: As noted earlier, even though European regulatory systems rely largely on public enforcement, they also allow the private beneficiaries of regulatory schemes to sue corporate offenders in court. Private litigants in Europe, however, look very different from class action representatives in the United States. In many cases, only specific civil society associations are allowed to sue, based on their membership numbers, organizational history, or other characteristics. Such requirements are designed to guarantee that private associations are representative of consumers, workers, environmental interests, or other classes of regulatory beneficiaries (Hensler, this volume). ${ }^{11}$

So far, the discussion has been limited to Europe and the United States. The analysis of public-private relations in the law of newer democracies is more complex. Before democratization, the countries of Latin America were considered in the political science literature as belonging to the category of "state corporatism." This was a form of interest representation in which, as in neo-corporatism, relatively few interest groups and their peak associations were allowed a prominent role in policymaking, but in which, unlike neo-corporatism, the authoritarian state tightly controlled the existence and operation of such peak associations (Adams, 2004). The function of interest groups in state corporatism was also somewhat different from neo-corporatism: less than representing important market and civil society interests in the regulatory process, they served as a conduit in the corrupt and clientelistic networks through which public jobs and benefits were exchanged in return for popular support of the regime (Vellinga, 2004). Prior to the pluralization of electoral politics, East Asian countries were believed

10 As Stijn Smismans recounts later in this volume, the situation in the European Union and many European countries is more complex than can be related in this brief discussion. Advisory committees, today, influence rulemaking and lawmaking in tandem with a more recent process of public consultation, open to all. This process, however, is not pluralist in the American sense because it does not incorporate the formal equality of U.S. notice-and-comment rulemaking. Rather, in public consultations, government actors are vested with considerable discretion on whether and how to consult and judicial enforcement of consultation rights is minimal or non-existent.

11 As with rulemaking, the law in Europe on private regulatory enforcement has gradually become more expansive, and now contemplates a wider set of private actors. However, it still tends to vet those private actors more systematically than in the pluralist American case (Hensler, this volume). 
to represent yet another form of interest group participation in state policymaking: informal and highly one-sided involvement of powerful industry groups in the policymaking activities of strong bureaucracies (Bhatt and Kim, 2000; Ohnesorge, this volume).

Since democratization, these political and legal arrangements are breaking down. It is far from clear, however, what is taking their place. On the one hand, at least in most Latin American systems, the organization of private groups within society has pluralized immensely with democratization and the emergence of a vibrant civil society sector (Avritzer, 2002; Risley, 2015). On the other hand, the question of how the law governs private access to public rulemaking and whether, overall, that law is informed by a competitive or mediated, i.e., balanced, vision of state-society relations remains an open one. The evidence is mixed. Legal requirements similar to pluralist, American rulemaking procedure have recently been adopted in a number of East Asian jurisdictions, including Korea, Taiwan, and Japan (Baum, 2011; Ohnesorge, this volume), but without the aggressive judicial review characteristic of the American system (Huang and Law, this volume). The same is true for the very different, Latin American cases of Venezuela, the Dominican Republic, Mexico, and Brazil (for certain independent agencies). At the same time, many Latin American countries, including Brazil, Colombia, Chile, Costa Rica, and Mexico operate with public-private consultative councils, typically identified with neo-corporatism, on which the major business associations are represented, as well as, in a few cases, labor and other organized social groups (Schneider, 2010; Kröger, 2012; Patroni and Felder, 2012). The East Asian cases mentioned earlier also continue to operate with the institutionalized consultation of industry actors, through legally established advisory councils which are attached to different government ministries and which are responsible for different types of issues and policy areas (Schneider, 2010). What balance will be struck between these two forms of public-private relations remains to be seen.

Table I.3 summarizes pluralism and neo-corporatism and how they impact the different elements of law and regulation.

Lest these classifications appear too abstract to afford analytical traction on the commonalities and diversities that mark the global regulatory process, let us return to the examples of consumer tracking and parabens. The paradigms of public law are likely to have profound consequences for the path taken by consumer-tracking regulation throughout the world. Internet companies and privacy advocates can expect judicial review of any future consumer-tracking rules to operate quite differently depending on the jurisdiction in which they find themselves: in rule-by-law systems like Japan, a limited checking that the administrative regulation adheres to the letter of the parliamentary statute; in the European fundamental rights model, a rough balancing test involving the rights to privacy, speech, and economic activity; in American ballot-box democracy, a meticulous sifting of the administrative record to make sure that the agency responded to all the objections entered by the rulemaking participants; and in Latin American transformative democracies, affirmative guidance on how to promote both the right to privacy and market freedom. Regulatory oversight of any future consumer-tracking rules will also differ: review by independent privacy commissions in Europe and Latin America; only more traditional forms of oversight, such as impact assessment by the executive branch in the United States; and relatively little oversight in Japan. Although it is difficult to anticipate policy outcomes, the regulatory 
Table I.3 Models of public-private relations

\begin{tabular}{|c|c|c|}
\hline & Pluralism & Neo-corporatism \\
\hline $\begin{array}{l}\text { Theory of } \\
\text { state-society } \\
\text { relations }\end{array}$ & Interest group competition & Interconnected solidarities \\
\hline $\begin{array}{l}\text { Constitutional law } \\
\text { on public-private } \\
\text { spheres }\end{array}$ & Strict separation & Mixed \\
\hline Public rulemaking & $\begin{array}{l}\text { Formally equal rights of private } \\
\text { participation, i.e., } \\
\text { notice-and-comment rulemaking }\end{array}$ & $\begin{array}{l}\text { Balanced representation of societal } \\
\text { groups on advisory committees }\end{array}$ \\
\hline $\begin{array}{l}\text { Private rulemaking } \\
\text { (self-regulation) }\end{array}$ & $\begin{array}{l}\text { - No legal recognition of specific } \\
\text { private bodies in public } \\
\text { regulatory schemes } \\
\text { - No state regulation of private } \\
\text { bodies }\end{array}$ & $\begin{array}{l}\text { - Legal recognition of private } \\
\text { bodies in public regulatory } \\
\text { schemes } \\
\text { - Balanced representation in private } \\
\text { bodies required under law }\end{array}$ \\
\hline $\begin{array}{l}\text { Regulatory } \\
\text { enforcement } \\
\text { initiated by private } \\
\text { parties }\end{array}$ & $\begin{array}{l}\text { Any individual as long as certified } \\
\text { by court as representative of class }\end{array}$ & $\begin{array}{l}\text { Associations representative of } \\
\text { regulatory beneficiaries }\end{array}$ \\
\hline Cases & United States & $\begin{array}{l}\text { European Union, European } \\
\text { countries, ISO/IEC (international } \\
\text { private standard setting) }\end{array}$ \\
\hline
\end{tabular}

results may also very well differ. Because regulatory problems like consumer tracking - and access to medicines, discrimination in the workplace, and many other regulatory issues-pit economic rights against other types of rights, the various elements of the regulatory process are likely to produce more restrictive rules in Europe and Latin America than in Japan and the United States.

The implications of the models of public-private relations can be illustrated with the parabens example. In the global debate over parabens safety, the divide between pluralism and neo-corporatism points to the key venues where the regulatory battle is being fought: administrative rulemaking procedure in the United States versus expert committees with stakeholder representation in the European Union. Bureaucrats in the United States are gathering scientific and economic data on parabens from a variety of industry groups, research institutions, and consumer activists with an eye to surviving a contentious rulemaking procedure. European civil servants, by contrast, are drawing on input from their committees of scientific experts, industry representatives, and civil society groups, as well as less formal types of stakeholder consultation, to determine the dangers of parabens and the appropriate regulatory response. It is possible that these differences will affect not only the regulatory process but also regulatory outcomes: according to some accounts, pluralist rulemaking procedure is biased towards high-stakes business actors (Wagner, this volume), and therefore restrictions on parabens in cosmetics and other products, currently less onerous in the United States, may stay that way. 
Convergence: legal transplants and diffusion

Although there are many possible ways of theorizing and explaining legal convergence, the field of comparative law has focused on one line of theory building in particulartransplants, as the phenomenon is known in comparative law (Watson, 1974), or diffusion, as it is known in a related avenue of inquiry in the social sciences (Weyland, 2006; Dobbin, Simmons, and Garrett, 2007). ${ }^{12}$ Research in the law and social sciences shares the common premise that legal systems are interdependent and that when convergence is observed it can be explained, at least in part, by the decision of legal and political actors in one jurisdiction to follow prior developments in another jurisdiction (Graziadei, 2008; Simmons, Dobbin, and Garrett, 2008). In line with this premise, scholarship in both traditions generally employs a sequential conceptual scheme of transfer and reception (Short, this volume). At the front end, under the influence of external forces, domestic elites make formal legal commitments by entering into international agreements, enacting national laws, or adopting specific types of legal doctrines and jurisprudence. At the back end, entrenched social, legal, and political actors mobilize in favor of or against the transplanted law, which is either implemented, modified, or sidelined.

Even though they share common elements, research in the law and the social sciences on convergence has also been driven by distinctive empirical and theoretical concerns. In comparative law, the focus has been on core figures within the legal establishment-judges and legal scholars-and how they have drawn on foreign legal concepts to develop central, generally private law, elements of national legal systems (Watson, 1974; Ajani, 1995; Graziadei, 2003). In other words, the object of analysis has generally been common law doctrines (adopted by courts) and civil law codes (drafted by legal commissions and parliaments and interpreted by scholars and courts), and how their content has been inspired by foreign legal sources. The explanation for this tendency to borrow turns on the authority of foreign law in the eyes of legal elites and the relative insulation of legal elites, when formulating the rules that govern disputes, from the conflicts and scrutiny of ordinary politics. That foreign authority, in turn, is linked to characteristics such as historical vintage and completeness, for example Roman law, or representativeness, for example regional or worldwide trends reflecting a common law of mankind (Watson, 1974: 52, 99; Monateri, 1997-1998).

Turning to reception, comparative scholars have focused not so much on the empirical operation of legal transplants but on the broader normative issue of whether, in light of the deep-rooted, complex structures of the law and the symbiotic relationship between cultural identity and law, the transplant phenomenon is a desirable one (Nelken, 2003; Twining, 2005). In traditional comparative scholarship, the most foundational law of receiving jurisdictions, and therefore the most vulnerable to the disruptive potential of transplants, is the structure and content of private law: whether a system is common law or civil law, and within civil law countries, the type of code tradition to which it belongs. The fear is that legal concepts and principles drawn from one system may not work in the other. The field has traditionally been divided into two camps: between those who take a relatively sanguine view of transplants and trust that the borrowed concepts will be made to work by legal elites, although often in ways that

12 For a more thorough review of the literature, see Jodi Short's contribution to this volume. 
depart from their use in the jurisdiction of origin (Watson, 1974); and those who point to the potential for transplants to disrupt, and possibly undermine, the functioning of the law in the receiving jurisdiction (Allison, 1996; Legrand, 1997; Teubner, 1998). In a somewhat separate line of research, focused specifically on western legal transplants in developing countries, comparative scholars have brought to light the many absurd cases in which transplanted law is so far removed from social practices and local customs that it fails to take hold and is sidelined by other types of rules and forms of dispute resolution (Gillespie, 2006).

In contrast with comparative law, the typical object of analysis in the social sciences is a specific type of regulatory policy imposed by the state, together with the law underpinning that policy, such as environmental law (Holzinger, Knill, and Sommerer, 2008), corporate taxation (Cao, 2010), or the privatization of retirement schemes (Weyland, 2006). The domestic actors responsible for policy adoption are generally not core legal elites but bureaucracies, political executives, and legislatures that draw on external sources, including international organizations, international capital or civil society actors, and the experience of foreign countries. Significant theoretical efforts have been made to identify competing explanations and different mechanisms for policy diffusion (Maggetti and Gilardi, 2015). In one prominent formulation, there are four possible causal mechanisms: coercion exerted by powerful actors such as wealthy states and international organizations; competition among states for foreign investment and global market share; rational learning from the policy experiences of other jurisdictions; and emulation of policies that are perceived as normatively superior because of their prior adoption by certain leader jurisdictions or expert networks (Simmons, Dobbin, and Garrett, 2008).

There is also social scientific research on the domestic reception of the legal commitments made by policy elites. Although this literature is somewhat difficult to distill, perhaps because the notion of reception covers a variety of political and social processes that must occur before formal law can exercise real traction over human behavior, one theme does tend to emerge-fit. If a set of legal rules, institutions, or doctrines fits the domestic legal environment, it is more likely to take hold and regulate disputes among political and social actors rather than be confined to the paper of international agreements, domestic statute books, and sporadic court opinions. A number of different elements of fit have been identified: the extent of overlap between existing administrative structures and the new ones required by the diffused policy (Knill, 2001); the existence of domestic legal actors such as human rights NGOs (Koh, 1997) and corporate law firms (Halliday and Carruthers, 2009) with a concrete interest in mobilizing the transplanted law; and the accessibility and comprehensibility of the transplanted law to members of the domestic legal community by virtue of a shared legal history between the country of origin and the country of reception (Berkowitz, Pistor, and Richard, 2003).

As a first cut, the theories developed in comparative law and the social sciences can help understand how law travels in the global regulatory process. Rules on parabens and consumer tracking can sometimes migrate between jurisdictions, and the politics explored in the legal and social scientific literature point to possible explanations for when and why. At the same time, both sets of literature have largely overlooked the core of regulatory law-not the technical substance of parabens and consumer-tracking 


\section{8}

regulation but the fundamental procedure and principles of how that regulation is made, overseen, enforced, and reviewed. The failure to address head-on this regulatory law has limited the ability of the existing theories to explain and evaluate jurisdictional convergence and requires a reassessment of the theories. ${ }^{13}$

Begin with the transfer of law. As explained earlier, transfer is explained in comparative law as a function of the perceived authority of the external source of law and in the social sciences as a product of one of four, alternative mechanismscoercion, competition, rational learning, and emulation. In both research traditions, the role of power is fairly limited. In the legal literature, power is largely discarded as a motive for contemporary transplants because it is associated with the military force of nineteenth and twentieth century colonization (Graziadei, 2008). In the social sciences literature, the concept of power is central to the diffusion mechanism of coercion, which is linked to the express use of economic leverage by international organizations and wealthy countries to achieve policy change in dependent countries. The empirical work on the causes of diffusion, however, has produced scant evidence of coercion (Garrett, Dobbin, and Simmons, 2008: 346) and has come to emphasize the other three mechanisms (Gilardi, 2010; Maggetti and Gilardi, 2015).

The area of law covered by the field of comparative law and regulation raises the possibility that power may play a more central role in explaining legal transfer than is currently acknowledged in the transplant and diffusion literature. On the one hand, the actors involved in the global regulatory process are not only, or even primarily, the judges, legislators, and scholars of legal transplant theory, sitting in their domestic chambers and deliberately and opportunistically borrowing from foreign legal systems. They are also bureaucrats and government officials engaged in ongoing negotiations in a variety of international regulatory committees (Hofmann, this volume; Kelemen, this volume; Shaffer, this volume). These international political processes produce a constant stream of harmonized legal rules, yet national participation requires significant resources, and therefore it is highly plausible that power differentials among states are reflected in the rules which are then transferred to domestic jurisdictions (e.g., Gadinis, 2015). On the other hand, in contrast with the social scientific literature, the law that is being transferred not only involves the technical intricacies of specific regulatory policies, but also the fundamental law of the regulatory function-how policy is made, overseen, enforced, and reviewed. To exercise clout on such issues, government officials must be able to draw on an elaborate doctrinal apparatus, which in turn requires a well-developed legal establishment, which in turn requires significant national wealth and power. As a result, it can be quite difficult to disentangle the rational learning or emulation inspired by certain lead jurisdictions from the underlying condition of national wealth and power (Dobbin, Simmons, and Garrett, 2007: 455-57). If it is not possible to develop reliable, testable indicators that can distinguish among these different mechanisms, then, at least for certain areas of legal diffusion, categories other than power and coercion may not be particularly helpful. Not only do such

13 In this volume, Jodi Short exposes another weakness of the transplant and diffusion literature in the context of the global regulatory process: the failure to take seriously the diffusion of private regulation and to analyze how private actors, soft law, and non-state mechanisms shape regulatory law across multiple jurisdictions. 
categories undermine the purposes of collective knowledge building, but they generate significant normative confusion, given the quite different valence of coercion vis-à-vis rational learning and emulation.

Now consider reception. The public law and public-private classifications advanced in the previous section point to important cultural and structural differences that have been ignored in comparative law and the social sciences. What paradigm of public law or which model of public-private relations dominates in the receiving jurisdiction may operate as a source of fit and contribute to the empirical investigation of diffusion. To illustrate, the United States and the European Union may forge agreement on regulatory policies such as consumer privacy or chemicals safety. But as long as the two jurisdictions subscribe to dissimilar paradigms of public law and public-private relations, those policies will likely operate very differently in their respective jurisdictions. More specific issues such as consumer tracking and parabens will be decided through different procedures and public institutions and, in all likelihood, the two jurisdictions will generate a stream of regulation that will continue to diverge on the substance.

At the same time, any political attempt to alter this obstacle to convergencebasic regulatory law of receiving jurisdictions-triggers the normative debates of the comparative law literature. As already mentioned, transplant theory focuses largely on private law, the divide between the common law and the civil law, and the potential problems generated by introducing foreign elements, drawn from across the civil law-common law divide, into what are believed to be conceptually intricate, and culturally important, systems of legal authority. Research in comparative law and regulation shifts attention to the public law sphere and provides evidence of other culturally and theoretically significant differences in systems of law and legal authority. The countries that fall into one or the other category, as those which belong to either the common law or civil law tradition, do not necessarily represent radically different political and social worlds. Their law, however, is based on different historical and cultural premises as to how to organize regulatory governance. As domestic systems of regulatory law increasingly come under pressure to harmonize and globalize, it bears keeping in mind the historical traditions and theoretical commitments that underpin that law. The most recent generation of international trade and investment agreements, some of which are covered in this volume (Shaffer; Yackee), contains elements designed either to harmonize regulatory law, through common standards for rulemaking procedure and other elements of regulatory law, or to sideline it, with international dispute settlement mechanisms that replace judicial review in national courts. We take no sides in the normative debate on the desirability of transplants, which is best conducted for specific countries and specific areas of regulatory law. What is crucial to note, however, is that regulatory law is not simply a morass of technical rules but rather is part of a rich tradition of law and democracy, and therefore it is appropriate to use the analytical framework of transplants in comparative law to evaluate political efforts at transformation. ${ }^{14}$

14 See Nicola (2015) for a discussion of the normative stakes involved in the negotiations on the Transatlantic Trade Investment Partnership, one of the most important efforts at regulatory harmonization to date. 
Last, the field of comparative law and regulation points to an important site for transfer and reception that has been overlooked in the existing literature: international jurisdictions (Bignami, 2013: 1321-26). In comparative law and the social sciences, the primary target for transplants is the nation state. International jurisdictions are interesting only to the extent that they serve as a conduit for transferring regulatory policies to nation states. But again, regulatory procedures, principles, and institutions are also transplanted and, unlike the substance of regulatory policy which generally bites only at the national level, this type of law can govern the regulatory function in both national and international jurisdictions. Since domestic and international jurisdictions interact in the global regulatory process, it is quite possible that regulatory law migrates between both types of jurisdictions. To illustrate with international examples from this volume, it might be that the law that governs rulemaking by international financial networks (Zaring), oversight by WTO committees (Shaffer), enforcement through EU composite procedures (Hofmann), and dispute resolution by international investment tribunals (Yackee) is borrowed from domestic jurisdictions. ${ }^{15}$ In other words, transplants should be conceptualized as a single process that can operate in multiple directions: law can migrate sideways, from one country or group of countries to another, downwards, from international systems to the national level, and upwards, from national governments to the basic operating rules of international jurisdictions. By influencing the legal procedures and principles of international systems, government officials, firms, and other types of actors can expect to shape regulatory output over the long run (cf. Farber and O'Connell, 2010) and therefore the incentive to transfer regulatory law operates sideward, downward, and upward, to international jurisdictions.

Legal prescription based on comparison: the functional method

When regulatory operators navigate the myriad jurisdictions involved in the global regulatory process, they do not simply mobilize the positive law as it stands. They make normative arguments as to what the law should be. In a regulatory process marked by interdependence and globalization, legal comparison is generally an important, if not the dominant, argument used to justify domestic law reform and new international legal instruments. The resort to comparison is a pervasive rhetorical device, even though that comparison often includes only the regulatory actor's home jurisdiction and the law of a second jurisdiction that is allegedly superior or inferior to that of the home jurisdiction.

Although the use of comparison as an argument for law reform may seem self-evident, the techniques necessary to understand the law of different countries and to make principled recommendations based on that law are far less so. Since the codifications of the nineteenth century, the categories and concepts of the law have developed within the confines of the nation state. Because of these historical and cultural particularities, it can be difficult for legal and political actors, schooled in the law of one sovereign, to travel intellectually to the territory and law of another

15 David Zaring and Jason Yackee specifically consider this hypothesis. However, the fluid institutional context and the current state of the literature prevent them from coming to any firm conclusions. 
sovereign. There are many possible ways in which these borders can be overcome and comparative analysis can be used in support of law reform projects.

The academic discipline of comparative law has elaborated a principled approach to comparing in the service of evaluating and prescribing law-the functional method. Since the early twentieth century, the discipline of comparative law has been profoundly shaped by the prescriptive mission, albeit almost exclusively in the private law domain (Zweigert, 1951; David, 1955; Farnsworth, 2008; Zimmermann, 2009). Because commerce was global, there was a real political demand for the comparative study of contract law that could serve to improve national law and, even more important, could create the harmonized, international law that would facilitate global commerce. Some of the oldest and most prominent institutions that fund comparative work are dedicated to the international unification of contract law-to name but a few, the International Institute for the Unification of Private Law, the United Nations Commission on International Trade Law, the Commission on European Contract Law, and the Study Group on a European Civil Code (Basedow, 2014).

To do the prescriptive work, the comparative law discipline developed a series of legal techniques, known collectively as the functional method. Although there are different types of organizations and political projects that can draw on comparative analysis to make new law, the most prominent traditionally have been domestic legislatures, international treaty negotiators, and international organizations. And although the aim was sometimes simply to improve the law, in the overwhelming majority of cases the ambition was also to create uniform law, on the theory that it would facilitate commercial exchange and human relations globally. With the functional method, this highly ideological and ambitious mission of creating uniform law was converted into a series of routine steps: establish a common problem, shared by multiple jurisdictions, such as the formation of contracts; identify the legal solutions to that problem that exist in each of the jurisdictions; and assess the degree of similarity or difference that marks the various legal solutions (Zweigert, 1951; David, 1955; Schlesinger, 1968; Zweigert and Kötz, 1998). If the comparative analysis revealed a common solution, then, especially in the context of law unification, this was the legal solution to be recommended to lawmakers (Zweigert and Kötz, 1998: 24). If it was not possible to find a common approach, or if the goal was strictly limited to improving domestic law, then the different solutions were evaluated to understand what was the "better" law to be recommended to lawmakers (Zweigert and Kötz, 1998: 47). To identify and assess the law of the various jurisdictions, such politically driven comparative projects generally limited themselves to the law on the books, not the law in action, and therefore they relied on the methodologies internal to the legal discipline rather than the empirical methodologies of the social sciences. This approach to comparative research has been very powerful in the legal academy. It has profoundly influenced the contribution that has been made by scholars of comparative law to political projects of domestic law reform and international law unification.

With the globalization of the regulatory process, the functional method of private comparative law can be used equally productively in the domain of public law. The use of comparison, as a rhetorical device in support of legal prescription, has become increasingly prominent in the area of regulatory law (e.g., Linos, 2013). The legal techniques and research approach of the functional method should be used to assess, 
critique, and improve comparative argument in the global regulatory process. At the same time, it is important to recognize that the functional method has a number of flaws, which are particularly stark in the area of regulatory law, and which require significant methodological innovation. Because the functional method is closely associated with the political project of international legal harmonization, it is heavily biased toward finding similarity (Hill, 1989; Michaels, 2008). Researchers are instructed that, in most cases, the foreign jurisdiction will contain a legal solution to the problem and that even though the doctrinal niceties of the legal solution might vary, the practical end result_-who wins and who loses when the legal solution is applied-will generally be the same (Zweigert and Kötz, 1998: 39-40). A common legal solution, particularly in the international arena, is both normatively and politically preferable: because it is common, it carries the moral status of universal or natural law, and it circumvents the potentially contentious political debates on which, among the different laws, to pick as the single, harmonized law (Örücü, 2004). The desired result of similarity can shape the method used to frame questions, design research, and draw conclusions. For the outcome to drive the research design is obviously troublesome from a scholarly perspective but when comparative research is so closely connected to politics, the bias toward similarity has the added consequence of legitimizing the project of law unification and minimizing the implications of legal change.

To be sure, the functional method does acknowledge that on some common problems, there are significant differences in legal solutions among jurisdictions. It does not, however, provide sufficient intellectual tools for analyzing the different solutions and coming to principled conclusions as to which one makes for the "better" law (Hill, 1989; Michaels, 2008). Two criteria that are often mentioned are doctrinal completeness and legal certainty (Zweigert and Kötz, 1998), but that hardly exhausts the list of attributes that make law desirable. In addition, until recently, the discipline of comparative law has made relatively little effort to use empirical methodologies to evaluate how the law operates in society (Hirschl, 2005; Spamann, 2015). Empirical methodologies are closely tied to the logically prior step of determining the normative criteria that should be used to evaluate the law and select the better law. Many laws have, on their face, desirable purposes which are not achieved in practice and it is only through empirical investigation that it is possible to measure the gap between normative ambitions and practical consequences.

Although these shortcomings of the functional method have been noted elsewhere, they are particularly acute in the domain of comparative law and regulation. While it might have been possible, at one time, to minimize the political stakes in areas of private law like contracts, that is certainly not the case in an area like regulatory law. When, as with regulatory law, national law is informed by theoretically and culturally important commitments to the legitimate organization of markets and democracy, the presumption should not be similarity of legal solutions. Especially in light of the political consequences of international law unification and harmonized regulatory law, comparative research should not be designed to give a false impression of similarity. By the same token, if difference is revealed, it is crucial to be explicit as to what makes for better law and why. To return again to the example of contract law, it is at least plausible to take an "I know it when I see it" approach to recognizing the better law: since one of the common purposes of contract law is to facilitate private transactions, it 
may be possible to use, without much justification, normative criteria such as clarity and simplicity to evaluate that law. In the domain of law and regulation, by contrast, the different theories of public law and public-private relations caution against assuming agreement on the normative criteria for assessing law. Instead, it is necessary to explicitly identify and justify why some institutions, procedures, and principles are better than others.

To be complete, comparative analysis should also employ empirical methods (Hirschl, 2014). Once the normative attributes of better law are singled out, it is important to assess those qualities based not only on the stated purposes of the law but also on its empirical operation. It is certainly true that empirical research can be time consuming and difficult and that it is important to set realistic expectations for research in comparative law, especially in the case of research driven by the immediate needs of law reform projects (Palmer, 2005: 263-64; Basedow, 2014: 857). In many cases, however, the relative merits of specific types of regulatory law have attracted sustained attention from legal scholars, beyond the imperatives of the latest reform project or policy initiative. Some of that scholarly effort can fruitfully be dedicated to the empirical investigation of the impact of law on regulatory politics and policies.

Since discussions of research approaches and methodologies can be quite slippery without concrete examples, it is worthwhile illustrating with examples from this volume. The book contains two chapters dedicated to assessing elements of American regulatory law that have been promoted as the benchmark, i.e., the better law, for international legal harmonization and domestic law reform: the procedure that governs administrative rulemaking and private class actions as a device for regulatory enforcement.

The chapter by Wendy Wagner considers U.S. rulemaking procedure. As explained earlier, since notice-and-comment rulemaking provides for formal equality among private groups in the public rulemaking process, it represents the pluralist category of public-private relations. It is often claimed to be the better law, as compared with neo-corporatist and other forms of private participation, precisely because of the extensive, and formally equal, participation that is guaranteed in administrative rulemaking. Wagner subjects this claim to thorough empirical scrutiny, including a large-N study of her own. She finds that even though the formal law, on its face, is extremely participatory, the legal incentives created for bureaucrats and market actors can lead to quite the reverse: high-stakes industry actors are generally favored over diffuse public interest groups.

Deborah Hensler, in her analysis of private class actions, systematically reviews the normative reasons why class actions might be the better law-efficient management of mass claims, ensuring that small-value claims will be compensated ("collective redress"), and improving the enforcement of economic regulation. The chapter then moves to a sustained investigation of the enforcement objective. It analyzes the existing empirical data on private class actions, which include a number of large-N studies on the United States as well as one on Israel and one on Australia, to assess whether private class actions can effectively enforce economic regulation. Ultimately, Hensler finds that the evidence is inconclusive and makes a proposal for a class action database that would considerably improve empirical efforts going forward. In sum, these two contributions on rulemaking and regulatory enforcement adopt the comparative method 
proposed here: they isolate the attributes of law that, in their view, make it normatively preferable and they employ empirical methodologies to assess whether the law from a particular jurisdiction or set of jurisdictions does, in fact, possess those attributes.

To conclude this discussion of how prescription based on comparative law should be conducted, it bears highlighting that, as with the theorization geared at mapping legal variation through classifications and explaining convergence through legal transplants, the field incorporates both domestic and international jurisdictions. In contrast with the earlier view of international organizations as merely instruments of states, the contemporary consensus is that, at least in the regulatory domain, international bodies can exercise power independent of their member states and therefore should themselves be governed by law (Alvarez, 2005; Kingsbury, 2009; Stewart, 2014). In principle there is no reason why, in developing that law and regulation, lessons cannot be learned from other jurisdictions, including domestic jurisdictions (Schill, 2010), and, vice versa, why the constructive projects of domestic jurisdictions cannot be informed by the experience of international bodies (Whytock, 2004: 191-93). Certainly there are significant differences in institutional and legal context that separate the domestic sphere from the international one and that can make it difficult to draw lessons. But, as revealed by the discussion of reception in transplant theory, there are also profound differences that separate national legal systems and that make it difficult for law to travel; yet normative analysis based on cross-national comparisons is standard fare in the legal academy. Especially now that international regulatory activity has intensified and a great variety of international bodies have been established, it has become increasingly difficult to make the intellectual case for separating international from domestic jurisdictions in comparative research aimed at improving the law. The regulatory process stretches across national and international jurisdictions, as do political demands for law to govern the regulatory process, and the rigorous comparison of regulatory law, wherever it is to be found, can assist with the global project of constructing law.

\section{Table I.4 Main lines of theoretical development in comparative law and regulation}

\begin{tabular}{|c|c|c|c|}
\hline $\begin{array}{l}\text { Key } \\
\text { characteristics of } \\
\text { the global } \\
\text { regulatory process }\end{array}$ & $\begin{array}{l}\text { Differences and } \\
\text { commonalities between } \\
\text { jurisdictions }\end{array}$ & $\begin{array}{l}\text { Convergence (or } \\
\text { divergence) of } \\
\text { jurisdictions over time }\end{array}$ & $\begin{array}{l}\text { Legal prescription based on } \\
\text { comparison across } \\
\text { jurisdictions }\end{array}$ \\
\hline $\begin{array}{l}\text { Lines of } \\
\text { theorization }\end{array}$ & $\begin{array}{l}\text { Classifications based on } \\
\text { the following categories: } \\
\text { - paradigms of public } \\
\text { law: rule by law, } \\
\text { fundamental rights, } \\
\text { ballot-box democracy, } \\
\text { transformative } \\
\text { democracy; } \\
\text { models of } \\
\text { public-private } \\
\text { relations: pluralism vs. } \\
\text { neo-corporatism }\end{array}$ & $\begin{array}{l}\text { Study of transplants with } \\
\text { emphasis on: } \\
\text { - power imbalance as a } \\
\text { mode of legal transfer; } \\
\text { - paradigms of public } \\
\text { law and public-private } \\
\text { relations as sources of } \\
\text { successful or } \\
\text { unsuccessful legal } \\
\text { reception }\end{array}$ & $\begin{array}{l}\text { Adaptation of functional } \\
\text { method }^{a} \text { from comparative } \\
\text { private law: } \\
\text { - no presumption of similarity } \\
\text { when assessing legal } \\
\text { solutions; } \\
\text { - if different solutions, } \\
\text { explicitly posit attributes of } \\
\text { "better" law and investigate } \\
\text { empirically which } \\
\text { jurisdiction's law possesses } \\
\text { such attributes }\end{array}$ \\
\hline
\end{tabular}

Note: ${ }^{a}$ The traditional functional method entails the following steps: definition of a common social problem; identification of the legal solutions in the jurisdictions under investigation; analysis of whether these solutions are similar or different; in the case of difference, identification of the "better" solution. 
Table I.4 summarizes the characteristics of the global regulatory process and the corresponding lines of theoretical inquiry that are fundamental to the field of comparative law and regulation. It bears repeating that here, as in the rest of this chapter, the term "jurisdiction" is used to refer to both international and domestic jurisdictions.

\section{OVERVIEW OF THE VOLUME}

The chapters provide wide-ranging coverage of the law of the regulatory function that has been identified as the subject matter of comparative law and regulation. For purposes of clarity, the presentation of the law and the organization of the chapters move from the most traditional venue for regulating-public authorities in domestic jurisdictions - to what are considered relatively novel regulatory arenas - private bodies and international jurisdictions. The following overview highlights, for each chapter, the specific regulatory law covered. It also explores the contribution made by the individual chapters to the lines of theoretical analysis important for understanding the global regulatory process and central to the field of comparative law and regulation. To repeat: paradigms of public law and models of public-private relations to capture jurisdictional differences and commonalities; diffusion and legal transplants to explain convergence over time; and the revised functional method to improve legal prescription based on comparison. Taken together, the chapters demonstrate the value of establishing a research agenda and creating a reservoir of knowledge dedicated to comparative law and regulation.

\section{The Regulatory State Across the Globe}

The first section of the book sets the stage by surveying the historical development of law and the regulatory state in the United States, the European Union, and East Asia. Since the United States did not experience the massive expansion of public ownership and industrial planning that was common to many post-war democracies and has always relied extensively on regulation to intervene in markets, it is often taken to be one of the first examples of the contemporary regulatory state (Levi-Faur, 2005; Yeung, 2010). Indeed, in American legal scholarship, the terms "regulation" and "administrative agency" are often used interchangeably with "administration" and "bureaucracy", not as specific and more recently established sub-types of administrative activity and bureaucratic organization as in scholarship focused on other jurisdictions. In his chapter on the United States, Reuel Schiller identifies two important characteristics of the American regulatory state: the underdeveloped, "patchwork" organization and policy capacity of the state, especially the federal state, and the outsized influence of the judiciary and court-like administrative procedures on decisionmaking. Schiller shows how these qualities are related to an American ideology of distrust of the state, which has its origins in the introduction of wide suffrage before the development of a central state, and the obstructive institutional landscape of federalism, bicameralism, and locally oriented political parties. The end result, he argues, has been a relatively weak regulatory state with low policymaking capacity. 
As explained by R. Daniel Kelemen in Chapter 2, the rise of the regulatory state in Europe dates to the late 1970s, with market privatization, liberalization, and re-regulation at the national level, and, somewhat later, regulatory harmonization at the EU level. Turning specifically to the EU, Kelemen highlights three important characteristics of EU regulatory governance. First, EU regulation tends to be copious and stringent-reflecting the standards of "strict regulation" in member states such as Germany and France. Secondly, to implement and enforce regulatory norms, the EU empowers private litigants and courts - a regulatory style which Kelemen calls "Eurolegalism"- and increasingly it also uses EU agencies to coordinate and mobilize networks of national regulatory agencies. And thirdly, because of the logic of the global regulatory process, the strict EU regulation generated in Brussels has deeply influenced the policy choices of other jurisdictions.

The section concludes with the regulatory state in East Asia. To recall briefly the earlier explanation of the field, as compared with Europe, the rise of the regulatory state in East Asia is associated less with a change in what states do-regulating - and more with a change in how they do it-in line with liberal democratic principles. As John Ohnesorge explains in Chapter 3, prior to the late 1980s, countries in East Asia were conceptualized as developmental states. Although there was little state ownership and most industry was in private hands, governments intervened heavily to direct investment and production in strategically selected market sectors and to manage trade and capital relations with the global market. This industrial policy was accomplished largely through opaque networks of firms and elite bureaucrats, with little involvement of parliaments, the courts, or civil society actors outside of business. The political changes of the late 1980s worked significant changes to the institutional dimension of the administrative state: with democratization (in Taiwan and South Korea) and greater party competition (Japan), the administrative process has become more formal and legalized. With respect to the content of state policymaking, the change has been less pronounced: the more passive regulatory model of setting rules for private market actors appears, as in the past, to be supplemented by a heavy dose of interventionist, state-driven industrial policy.

\section{Rulemaking}

The second section turns to rulemaking and one of the most visible ways in which rulemaking is shaped by law: the legal procedure that governs public participation when administrative authorities take the lead. The administrative authorities responsible for making rules, either alone or together with the legislature and the political executive, are often required by law to allow private parties to participate. This section covers the pluralist and neo-corporatist variants of rulemaking procedure that exist in the United States and the European Union.

In Chapter 4, Wendy Wagner analyzes the law and empirical realities of rulemaking procedure in the United States. This discussion is also relevant for other jurisdictions because of the efforts that have been made to transplant U.S. law, some of which are discussed in the last section of the volume. The chapter chronicles the elements of the pluralist law, known as notice-and-comment rulemaking, that require extensive private participation, formal equality among the parties, and government impartiality. As 
explained earlier, however, Wagner shows that the empirical reality is quite different: the pluralist law governing rulemaking generates incentives that enable high-stakes regulated parties, as opposed to public interest groups and small market actors, to participate more in the rulemaking process and to exercise a disproportionate influence over outcomes. The chapter concludes with policy prescriptions, inspired by EU law, for remedying the representational imbalances in U.S. rulemaking.

In Chapter 5, Stijn Smismans turns to the law of rulemaking in the European Union. Historically, neo-corporatist advisory committees of industry, labor, environmental, consumer, and other societal groups were the most important form of rulemaking procedure; still today, they are central to the regulatory process, numbering well over eight hundred. Since the EU's legitimacy crisis of the 1990s, advisory committees have been joined by additional legal procedures. Some of these procedures have been inspired by the neo-corporatist impulse to privilege more representative groups in the policymaking process and others have been designed to facilitate full and free competition among all societal actors, more in the pluralist mold. Smismans concludes that the current rulemaking system should be conceptualized as "pluralisation without proceduralisation" - expanded opportunities for participation by a wide array of actors without legalistic enforcement of procedural rights in court, as is characteristic of the American system. Although the EU system suffers from representational imbalances, Smismans argues that there is no reason to move towards the more judicialized American model in light of the empirical realities discussed in Wagner's chapter.

\section{Oversight}

Although political and bureaucratic oversight can occur at any time during the regulatory process, the law of oversight tends to bite after the essentials of the rules have been decided. The section begins with impact assessment, which is a legal tool for evaluating the environmental, social, and economic impacts of government regulation. As Jonathan Wiener and Daniel Ribeiro explain in Chapter 6, there are two common forms of impact assessment today: environmental impact assessment, which is triggered by public projects and other types of government initiatives that affect the environment; and regulatory impact assessment, which considers both costs and benefits (generally economic, environmental, and social) and is applied to all types of regulatory policymaking. Both were adopted first in the United States and have since diffused throughout the world, although with significantly different institutional characteristics. The authors point to the proliferation of impact assessments required of regulatory agencies and the many dysfunctions created by their overlapping and inconsistent legal obligations. To address these shortcomings, Wiener and Ribeiro call for "integration", namely a single approach that would be triggered by the same type of government action, consider one set of impacts, adopt the same analytical methods, and employ a single review process.

Chapter 7, by Ben Worthy, turns to another important form of regulatory oversight: transparency and, in particular, access-to-information laws in the UK and India. Under these laws, citizens have a right to the information held by government bodies within a fixed time period, enforceable before an independent body and the courts, and government authorities have a pro-active duty to disclose information to the public. The 
right to information has been the object of successive waves of diffusion across the globe and therefore represents an ideal area to investigate theories of transplants and diffusion. Worthy's chapter reveals how reception in the UK and India has been shaped by the paradigms of public law developed earlier in this introduction. Although there are similarities between their laws, the Indian experience has been marked by the transformative democracy paradigm. In contrast with the UK, where freedom-ofinformation legislation was but one piece of a larger package of modernization reforms, in India it was framed as a revolutionary moment that would transform a corrupt administration and open up political participation to excluded social and economic groups. The track record on the ground also reflects the different paradigms of public law. In the UK, a wide range of civil society actors make use of the law, including business and the press, and implementation has been fairly smooth. By contrast, in India the social justice and anti-corruption campaigners who are the heaviest users of the law routinely clash with a feudal bureaucracy over compliance. The conflict between the bureaucracy and the public has been quite dramatic, with reports of pervasive intimidation and violence.

\section{Enforcement}

The next stage of the regulatory process is enforcement. This section considers two important types of regulatory law that bite at this stage: the powers and procedures available to administrative officials and criminal prosecutors to enforce regulation; and class action litigation brought by the private beneficiaries of public regulatory schemes.

In Chapter 8, Benjamin van Rooij considers administrative and criminal enforcement in China. He focuses on what he calls the "campaign enforcement style", an institutional and legal device that in recent years has been deployed in a wide array of policy areas, including intellectual property, food safety, and employment and labor law. Enforcement campaigns are triggered by widely publicized episodes of policy failure that prompt the political leadership to take action and assert control over the bureaucracy. They involve a radical, brief change in China's standard enforcement style-lax and captured by industry - in which regulators resort to more formal and punitive tactics. In van Rooij's account, the campaign enforcement style is a product of the rule-by-law paradigm advanced earlier in this introduction: in the Chinese authoritarian system, enforcement campaigns are designed to establish rational bureaucratic authority, through enhanced hierarchical control, and to demonstrate a commitment to the letter of the law, by vigorously applying the law to all private actors. At the same time, enforcement campaigns also represent a form of authoritarian populism, deployed to demonstrate state responsiveness to the public and to maintain the legitimacy of the Communist Party. Van Rooij concludes by observing the use of similar enforcement campaigns to respond to policy failures and public outcry in the United States and the Netherlands. The pervasiveness of the phenomenon underscores that the law of regulatory enforcement is driven as much by the theoretical concern for policy effectiveness as by the political desire for popular legitimacy and authority, even in systems that afford greater protection for the fundamental rights of defendants.

Chapter 9, by Deborah Hensler, analyzes private class actions, a procedural device that allows one party to come forward and represent similarly situated others ("the 
class") in litigation to obtain relief from regulatory harms. Although class actions now exist in over twenty-five countries, Hensler reveals the considerable differences in their precise legal form, which have limited their availability in some jurisdictions and have influenced the types of private parties that are allowed to come forward and represent the class. As discussed above, Hensler reviews the substantial, but as it turns out, inconclusive empirical evidence on the effectiveness of class actions, and puts forward a research agenda for improving our knowledge of class actions. She also argues that in view of the well-known failures of public enforcement, policymakers should build "redundancy" into their systems and create and preserve the private enforcement track as a complement to the public one.

\section{Judicial Review}

Courts are omnipresent in regulatory law because of their role in both oversight and enforcement and because much of the legal framework that guides the regulatory process has been developed in their jurisprudence, not in the formal text of legislation and constitutions. Most commonly, however, courts intervene at the end of the regulatory process, in applications for judicial review of the rules or in defenses against enforcement actions. The chapters in this section illustrate the different paradigms of public law developed earlier in this introduction, which are most apparent in doctrines of judicial review.

In Chapter 10, I analyze the classifications used in the scholarly literature to capture variation in judicial review of government policymaking in Europe and the United States. Although these taxonomies apply to judicial review of the administrative state in general, the chapter also draws out their implications for the regulatory function. The earliest, and still relevant, divide is between judicial review of administrative action by the ordinary courts in the English common law and by a special body (Conseil d'Etat) connected to the executive branch in the French droit administratif. Almost a century after this first classification, Robert Kagan and others drew attention to the contrast between the litigious and formal American system of policymaking and the informal and discretionary European policy process. The chapter then proposes the fundamental rights and ballot-box democracy paradigms of public law. In Europe, the courts employ doctrines such as proportionality and equality to protect economic and social rights in government policymaking; in the United States, they impose extensive procedural requirements on the bureaucracy to promote pluralistic democracy within public administration. In light of the potential for diffusion, the chapter argues that it will be important to develop a research agenda to investigate empirically the effects of the two forms of judicial review on social and economic policymaking.

In Chapter 11, Cheng-Yi Huang and David Law turn to judicial review of administrative action in East Asia. They first present the rule-by-law paradigm that was historically dominant, and continues to figure prominently, in the law of Japan, Korea, and Taiwan-judicial review focused on the formal legality of whether administrative action respects the boundaries set down by law. The contribution then analyzes the variable reception of the doctrine of proportionality, drawn from the fundamental rights model and used by East Asian courts to scrutinize the substance of administrative determinations. Huang and Law observe that proportionality has had considerably more 
traction in Korea and Taiwan than in Japan and China. Part of the explanation for this variation, they suggest, is the presence of relatively new and powerful constitutional courts in Korea and Taiwan. These new constitutional courts have sought to establish their legitimacy by adopting what has emerged as the gold standard for constitutional review throughout the world, namely, proportionality. At the same time, even in Korea and Taiwan, the reception of proportionality has not been complete since in both jurisdictions a separate set of courts has traditionally been responsible for reviewing administrative action; these courts have been resistant to proportionality and have continued to adjudicate in the mold of rule by law.

In Chapter 12, Everaldo Lamprea, Lisa Forman, and Audrey Chapman analyze the operation of the transformative democracy paradigm in Colombia, specifically constitutional review of healthcare regulation. Like many other relatively new democracies, the Colombian Constitution of 1991 contains a comprehensive set of positive social and economic rights, including the right to health, and establishes an expansive system of constitutional adjudication, in which it is easy for individuals to bring constitutional complaints (tutela). As the chapter explains, implementation of Colombia's new healthcare system, introduced in the 1990s, was extremely problematic because of low administrative capacity and therefore patients turned, in the hundreds of thousands, to the courts based on their constitutional right to health. In 2008, the Constitutional Court sought to address some of the systemic failures of the healthcare system (and stem the rising tide of litigation) with a landmark decision (T-760) that outlined a number of structural reforms for government policymakers. It also created a monitoring process, led by a specially created follow-up panel of the Court. Overall, the chapter's assessment is positive: the remedies ordered by the Constitutional Court allowed for considerable government discretion; civil society actors were called upon to participate; and the process resulted in concrete improvements to the healthcare system that very likely would not have been made in the absence of constitutional law and judicial review.

This section concludes with Chapter 13 by Susan Rose-Ackerman, Stefanie Egidy, and James Fowkes. They analyze judicial review in the United States, Germany, South Africa, and the European Union, both judicial review of the rules adopted by administrative authorities and those adopted by legislative assemblies. The chapter argues in favor of judicial review designed to promote democratic participation in generating the rules, reflecting to some extent U.S. law for administrative rulemaking and South African law for legislative rulemaking. The analysis is heavily informed by positive political theory, which focuses on the strategic incentives of political actors, and, in the comparative context, on how those incentives differ between parliamentary and presidential systems. The chapter highlights how political actors in both types of systems resist democracy-enhancing judicial review. It also argues that, relative to parliamentary systems, judicial review of legislative rulemaking should be somewhat less demanding in the U.S. presidential system because of the inevitably piecemeal nature of legislation when the executive branch, i.e., the President and the bureaucracy, plays a relatively minor role in legislative drafting. 


\section{Private Regulation and New Governance}

Although private bodies have always undertaken regulatory functions, in lieu of public institutions, they have become more important since the 1990s with the growing popularity of new governance regulatory techniques. In contrast with the classic model of prescriptive rules enforced by government agencies, new governance tools are generally highly flexible and vest significant initiative and power in private actors. This volume considers three prominent forms of new governance-industry standard setting, performance-based regulation, and private codes of conduct-which empower three categories of business actors - industry associations, individual firms, and multinational corporations. The contributions also highlight different aspects of the regulatory process that can be handled by private bodies: rulemaking in the chapters on standard setting and performance-based regulation and enforcement in the chapter on private codes of conduct.

In Chapter 14, Peter Strauss chronicles the extensive reliance, in both U.S. and EU regulation, on the private technical standards set by industry associations. Strauss reviews some of the differences, along the lines of the neo-corporatist and pluralist models, that separate how private industry associations are regulated in the EU and the U.S. The bulk of the chapter addresses the troublesome practice, in U.S. regulation, of incorporating by reference, and making binding, the technical standards set by industry organizations, even though those standards are protected by copyright and must be purchased from the relevant industry organization. This lack of transparency, or "secret law" as Strauss calls it, generates significant accountability problems and, for a possible fix, the chapter looks to the EU. There the law requires that the "essential requirements" of standards be stated on the face of the regulation and industry technical standards are considered soft, not binding, law, meaning that compliance with such standards is but one way of demonstrating compliance with the "essential requirements." To restate in the language of the functional method discussed above, Strauss argues that the EU approach-essential requirements plus soft law standards-is the better solution to the common problem of copyright-protected industry standards. In his view, this better solution offers a possibility for improving U.S. law.

Chapter 15, by Cary Coglianese, systematically assesses performance-based regulation, a darling of regulatory reformers across the world. Performance-based regulation works not by specifying the means of compliance, but rather by requiring particular performance or outcome goals. The idea is that regulated firms will determine for themselves how to achieve those goals. Based on the American experience, Coglianese assesses the merits of performance-based regulation and argues that it can be superior to classic command-and-control regulation but only under a particular, and by no means universal, set of circumstances: when the policy problem and regulatory capacity are such that firm performance is likely to be assessed accurately and when the regulated industry is relatively heterogeneous. In such cases, the sector can adapt to performance-based goals in different ways, perhaps promoting innovation, and at the same time regulators can evaluate whether those goals have been met and compliance has been achieved.

Chapter 16 on private transnational regulation, by Jodi Short, serves as a bridge between the part of the volume focused on private bodies and the part dedicated to 
international regimes. The chapter highlights recent empirical research on one important facet of transnational private regulation: codes of conduct that are used by multinational corporations to set labor standards for their supply chain factories and that are enforced, at least in part, by private auditing firms. In a recent, large-N study, Short and her co-authors demonstrate that compliance with transnational labor standards - to refer back to the earlier discussion, the domestic reception of transplanted law-varies systematically across national jurisdictions. In particular, four factors contribute to compliance: ratification of ILO conventions by the state in which the factory is located; highly protective domestic labor regulation; high levels of press freedom; and, in the buyer markets served by the multinational corporation, a wealthy and socially conscious consumer base. As Short argues, this and other research on private transnational regulation makes an important contribution to the comparative law theory of transplants. The transplant literature has traditionally focused on diffusion of formal law by state actors, not the increasingly important phenomenon of diffusion of self-regulatory norms by private actors. It has also failed to investigate through large-N studies the implementation and effectiveness of legal transplants.

\section{International Jurisdictions}

The last section of the volume is dedicated to international regulatory systems. International jurisdictions have come to function increasingly as independent sites of regulatory power that interface with domestic jurisdictions and other international bodies in the global regulatory process. Depending on the system, international bodies can intervene at any stage of the regulatory process-rulemaking, oversight, enforcement, and judicial review. International jurisdictions vary considerably, both in the scope of their powers and their degree of legal formality, and this section is designed to include a representative subset.

In Chapter 17, Gregory Shaffer develops a novel analytical framework for understanding the interplay between domestic jurisdictions and the World Trade Organization. The chapter proposes a four-part scheme, supported by numerous examples, for understanding and assessing the impact of the WTO on national regulatory governance: (1) changes in the boundary between market and state through the liberalization of markets and the reconfiguration of national regulation; (2) a shift in the balance of institutional power in favor of administrative and judicial actors; (3) the creation of new professions, primarily legal and economic, that work with the new WTO rules and promote the WTO agenda; and (4) the spread of free market normative frames that shape national perceptions of permissible and appropriate policy options. To return to causal theories of diffusion, the WTO illustrates a number of different mechanisms by which international jurisdictions transfer law to participating states, including power as highlighted in the previous discussion. The WTO's eighteen multilateral agreements on issues ranging from customs inspections to food safety are implemented by the Dispute Settlement Body and over seventy multilateral committees, which meet, according to conservative estimates, over 1,000 times per year. Participating effectively, not to mention just showing up, requires considerable resources and systematically disadvantages smaller developing countries. At the same time, the type of regulation that diffuses is not necessarily the ultra-liberal, deregulatory law that is associated with 
power in certain accounts of globalization. Rather, as Shaffer explains, because the governments and firms that exercise power in the global regulatory process generally come from wealthy, high-regulation jurisdictions, they have significant strategic incentives to export those high regulatory standards to other jurisdictions. For instance, they can push for western product standards in international committees or they can provide technical assistance to developing countries to support protective regulatory schemes. The importance of the potential "race to the top" in global regulation is underscored in the earlier chapters by Kelemen and Short, which reveal similar pro-regulatory mechanisms at work in the European Union and multinational corporate codes.

In Chapter 18, Jason Yackee turns to international investment law and conducts a wide-ranging analysis of how this international system interacts with domestic jurisdictions in the global regulatory process. As Yackee explains, bilateral investment treaties (and investment chapters in bilateral and multilateral trade agreements) generally protect foreign investors against expropriations and regulatory takings by establishing principles of non-discrimination and fair treatment and by giving foreign investors the right to sue states in ad hoc arbitral tribunals. In recent years, investment treaties have also been used by the United States to transplant administrative law to other countries, in particular the pluralist rulemaking procedure that is considered earlier in the volume. At the same time, in light of the potentially far-reaching consequences of investor-state dispute resolution for domestic regulation, there have been a number of constructive efforts to design a better legal framework for international arbitral tribunals. These include enhanced transparency and third-party participation in investor-state arbitrations. Overall, Yackee is cautious in his assessment of these many developments. Domestically, because of the legal obstacles to reception noted earlier, he is skeptical that rulemaking procedure will operate as intended. Internationally, the international investment regime is characterized by a relatively low level of institutionalization and therefore investors and states can fairly easily circumvent any unwelcome legal requirements that emerge in investor-state arbitration.

The volume then presents one of the leading examples of an informal, but nevertheless highly powerful, international regulatory regime: international financial networks. As David Zaring explains in Chapter 19, international networks of financial regulators-one each for the banking, securities, and insurance industries-have sought for over four decades to coordinate policies and develop common regulatory standards. Compared with international regimes like the WTO or bilateral investment treaties, regulatory networks are highly informal: they are not established by treaty, but rather are created and operate pursuant to memoranda of understanding and other low-level agreements between national regulatory agencies; their membership is not global but is limited to the wealthy countries with the most developed financial sectors; they do not have tribunals that can resolve disputes between their participating states; and their policy output, or, as Zaring says, their rulemaking, is not formally binding on their participating state regulatory agencies. At the same time, the banking network, in particular the Basel Committee, wields significant power by generating a considerable body of rules that has largely been implemented into national law by domestic regulators. Increasingly, related to this exercise of rulemaking power, a legal framework has emerged to discipline international financial networks. In addition to observing a number of substantive principles, Zaring argues that the Basel Committee subscribes to 
a notice-and-comment rulemaking procedure. Although in some respects this procedure mirrors pluralist U.S. rulemaking, it is not enforced by the courts, and therefore it affords less protection for formal equality and interest group competition.

The volume concludes with two cases that can be characterized as outliers on the spectrum of international jurisdictions involved in the global regulatory process. Chapter 20, by Herwig Hofmann, reveals the high degree of political, legal, and administrative integration that has occurred in the European Union since its founding in the 1950s. Nonetheless, as Hofmann explains, the EU's regulatory system relies on coordination among formally autonomous national regulatory authorities and has generally avoided instituting a free-standing set of government agencies, with independent constitutional powers of implementation and enforcement, as exists in federal systems like Germany and the United States. This structure of EU regulatory cooperation has been criticized on the grounds that it undermines the accountability and legitimacy of the regulatory process. Hofmann concludes that the accountability challenge is serious indeed, in part because legal prescription based on comparison does not have much purchase over the complex realities of EU governance. In domestic jurisdictions, the principal-agent model of legislatures and bureaucracies is generally used to craft the accountability principles of administrative law. By contrast, as Hofmann argues, the European Union operates with a dizzying array of principals and agents and therefore it cannot look directly to national experience to build greater accountability into EU administrative law.

The last chapter, by Eric Feldman and Chelsea Fish, analyzes the international system for managing natural and nuclear disasters, which as of yet has operated as a relatively insignificant jurisdiction in global disaster regulation. The explanation for the low level of international cooperation in the disaster area is twofold: the domestic foundations are underdeveloped since many countries, even wealthy ones such as Japan, lack a robust legal framework for disaster relief; internationally, especially with respect to natural disasters, countries lack a shared sense of reciprocal risk because the harms are often believed to be non-human in origin and geographically restricted. Feldman and Fish conclude that the best disaster relief programs reflect an ethic of social solidarity. This is a value which can be found across very different societies and legal systems and which, in the future, could serve as the foundation for an effective international system of disaster regulation.

\section{CONCLUSION}

The contemporary regulatory process is global. Markets and the problems they generate-consumer tracking, parabens safety, and many others-cross borders and so too do regulatory efforts to address those problems. As national sovereignty recedes and markets and jurisdictions become increasingly interdependent, the high-stakes game of regulation is no longer being played within the confines of the state and the law of single nations. A plurality of jurisdictions and regulatory bodies are called into action, sometimes in concert but just as often in competition.

The field of comparative law and regulation is designed to create the intellectual foundations for analyzing and assessing this global regulatory process. It does so by 
defining an object of legal study that is unconfined by the traditional organization of the legal discipline and that is capable of sweeping in the law of the regulatory function across the world. The field is thus flexible enough to include the wide array of domestic and international jurisdictions that are mobilized in the effort to regulate global policy problems. The field also rises to the intellectual challenge of the global regulatory process by identifying three critical features of that process that require different types of theoretical inquiry. Jurisdictional diversity and similarity are best captured by classifications based on paradigms of public law and models of public-private relations. The question of whether and how convergence occurs should be studied using causal theories of legal transplants and diffusion. In particular, it is important to investigate how disparities in political and economic power influence the transfer of regulatory law and how the paradigms of public law and models of public-private relations shape the reception of regulatory law. Legal prescription based on comparison, a favorite rhetorical device in the global regulatory process, should be evaluated based on a normatively explicit and empirically sensitive functional method of comparative law research. These are characteristics that cut across the many domestic and international jurisdictions involved in regulation and that should be analyzed using the same conceptual and theoretical tools regardless of where they are to be found, domestically or internationally. Today's regulatory process may be complex and may fail to fit the traditional mold of hierarchical state law that applied when regulation occurred primarily within national borders. But it is still possible to bring intellectual order to the contemporary reality of the global regulatory process.

The chapters in this book afford a vital demonstration of what is to be gained by establishing a new field of inquiry. They show the value, for the various political and legal operators engaged in the global regulatory process, of presenting and analyzing in a single work the diverse elements of law that govern the regulatory process and that shape regulatory outcomes. The contributions to this volume also illustrate the productive scholarly conversations and theoretical advances that can be made by analyzing a single set of questions across the whole gamut of regulatory law, in both domestic and international jurisdictions, and applied to both public and private actors. In sum, taken together, the chapters that follow reveal the practical and theoretical payoffs that come from staking out an independent domain of research and knowledge building dedicated to understanding the global regulatory process.

This book provides an important statement of the field of comparative law and regulation. But the research agenda of the field is ambitious. As explained above, regulatory law includes manifold topics and jurisdictions. This book covers some of the most important ones, but a number of others have been left to future research endeavors. Likewise, the avenues of theoretical inquiry that are central to the field are complex and will require sustained investigation over time to build a solid understanding of the global regulatory process. Legal scholarship must keep up with the worldwide expansion of regulation. The field of comparative law and regulation sets out a disciplinary road map for advancing on this new, global terrain. 


\section{REFERENCES}

Ackerman, John. 2010. "Understanding Independent Accountability Agencies," in Susan Rose-Ackerman and Peter Lindseth, eds., Comparative Administrative Law. Cheltenham, UK and Northampton, MA: Edward Elgar Publishing.

Adams, Paul S. 2004. "Corporatism in Latin America and Europe: Origins, Developments, and Challenges in Comparative Perspective," in H.J. Wiarda, ed., Authoritarianism and Corporatism in Latin AmericaRevisited. Gainesville, FL: University of Florida Press.

Ajani, Gianmaria. 1995. "By Chance and Prestige: Legal Transplants in Russia and Eastern Europe," 43 American Journal of Comparative Law 93-117.

Albert, Richard. 2014. "The Structure of Constitutional Amendment Rules," 49 Wake Forest Law Review 913-75.

Allison, J.W.F. 1996. A Continental Distinction in the Common Law: A Historical and Comparative Perspective on English Public Law. Oxford: Oxford University Press.

Allison, J.W.F. 2007. The English Historical Constitution: Continuity, Change and European Effects. Cambridge: Cambridge University Press.

Alvarez, José E. 2005. International Organizations as Law-Makers. Oxford: Oxford University Press.

Avritzer, Leonardo. 2002. Democracy and the Public Space in Latin America. Princeton, NJ: Princeton University Press.

Basedow, Jürgen. 2014. "Comparative Law and its Clients," 62 American Journal of Comparative Law 821-57.

Baum, Jeeyang Rhee. 2011. Responsive Democracy: Increasing State Accountability in East Asia. Ann Arbor, MI: The University of Michigan Press.

Bell, John S. 2008. "Comparative Administrative Law," in Mathias Reimann and Reinhard Zimmermann, eds., The Oxford Handbook of Comparative Law. Oxford: Oxford University Press.

Berkowitz, Daniel, Katharina Pistor, and Jean-Francois Richard. 2003. "The Transplant Effect," 51 American Journal of Comparative Law 163-203.

Bhatt, V.V. and Hyung-Ki Kim. 2000. "Japanese Civil Service System: Relevance for Developing Countries," Economic and Political Weekly 1937-43, June 3.

Bickel, Alexander. 1962. The Least Dangerous Branch: The Supreme Court at the Bar of Politics. Indianapolis, IN: Bobbs-Merrill.

Bignami, Francesca. 2007. "European Versus American Liberty: A Comparative Privacy Analysis of Antiterrorism Data Mining," 48 Boston College Law Review 609-98.

Bignami, Francesca. 2011a. "Cooperative Legalism and the Non-Americanization of European Regulatory Styles: The Case of Data Privacy," 59 American Journal of Comparative Law 411-61.

Bignami, Francesca. 2011b. "From Expert Administration to Accountability Network: A New Paradigm for Comparative Administrative Law," 59 American Journal of Comparative Law 859-907.

Bignami, Francesca. 2013. "Rethinking the Legal Foundation of the European Constitutional Order: The Lessons of the New Historical Research," 28 American University International Law Review 1311-35.

Black, Julia. 2002. "Critical Reflections on Regulation,” 27 Australian Journal of Legal Philosophy 1-35.

Bradford, Anu. 2012. "The Brussels Effect," 107 Northwestern University Law Review 1-67.

Braithwaite, John, and Valerie Braithwaite. 1995. "Rules versus Standards in Nursing-Home Regulation," 4 Social \& Legal Studies 307-41.

Breyer, Stephen G., Richard B. Stewart, Cass R. Sunstein, Adrian Vermeule, and Michael Hertz. 2011. Administrative Law and Regulatory Policy: Problems, Text and Cases. 7th ed. New York: Wolters Kluwer Law \& Business.

Büthe, Tim and Walter Mattli. 2011. The New Global Rulers: The Privatization of Regulation in the World Economy. Princeton, NJ: Princeton University Press.

Cao, Xun. 2010. "Networks as Channels of Policy Diffusion: Explaining Worldwide Changes in Capital Taxation, 1998-2006," 54 International Studies Quarterly 823-54.

Carmona, George V. 2011. "Strengthening the Asian Ombudsman Association and the Ombudsman Institutions of Asia in Asian Development Bank," in Strengthening the Ombudsman Institution in Asia: Improving Accountability in Service Delivery through the Ombudsman. Asian Development Bank.

Cassese, Sabino, ed. 2016. Global Administrative Law. Cheltenham, UK and Northampton, MA: Edward Elgar Publishing. 
Chinese Human Rights Defenders. 2014. “We'll Beat You to Death with Impunity": Secret Detention Abuse and Detention of Women in China's "Black Jails." Available at: https://chrdnet.com/2014/10/chrdreleases-well-beat-you-to-death-with-impunity-a-report-about-secret-detention-abuse-of-women-in-chinasblack-jails.

Coglianese, Cary and Robert A. Kagan. 2007. "Introduction," in Cary Coglianese and Robert A. Kagan, eds., Regulation and Regulatory Processes. Burlington, VT: Ashgate.

Dahl, Robert A. 1971. Polyarchy: Participation and Opposition. New Haven, CT: Yale University Press.

Damaška, Mirjan R. 1986. The Faces of Justice and State Authority: A Comparative Approach to the Legal Process. New Haven, CT: Yale University Press.

Dannemann, Gerhard. 2008. "Comparative Law: Study of Similarities or Differences," in Mathias Reimann and Reinhard Zimmermann, eds., The Oxford Handbook of Comparative Law. Oxford: Oxford University Press.

David, René. 1955. "Die Zukunft der europäischen Rechtsordnungen: vereinheitlichung oder harmonisierung?," in Konrad Zweigert, ed., Europäische Zusammenarbeit im Rechtswesen: Berichte und Vorschläge. Tübingen: Mohr.

David, René and John E.C. Brierly. 1978. Major Legal Systems in the World Today. 2nd ed. New York: The Free Press.

de Beco, Gauthier. 2009. Non-Judicial Mechanisms for the Implementation of Human Rights in European States. Bruxelles: Bruylant.

Dicey, A.V. 1885. Lectures Introductory to the Study of the Law of the Constitution. London: Macmillan and Co.

Djankov, Simeon, Rafael La Porta, Florencio Lopez-de-Silanes, and Andrei Shleifer. 2002. "Courts: The Lex Mundi Project," NBER Working Paper No. 8890.

Dobbin, Frank, Beth Simmons, and Geoffrey Garrett. 2007. “The Global Diffusion of Public Policies: Social Construction, Coercion, Competition, or Learning?" 33 Annual Review of Sociology 449-72.

Dubash, Navroz and Bronwen Morgan. 2012. "Understanding the Rise of the Regulatory State in the South," 6 Regulation \& Governance 261-81.

Dubinsky, Paul R. 2005. "Human Rights Law Meets Private Law Harmonization: The Coming Conflict," 30 Yale Journal of International Law 211-317.

Duguit, Léon. 1901. L'État, le droit objectif, et la loi positive. Paris: Albert Fontemoing.

Ely, John Hart. 1980. Democracy and Distrust: A Theory of Judicial Review. Cambridge, MA: Harvard University Press.

European Union Agency for Fundamental Rights. 2010. Data Protection in the European Union: The Role of the National Data Protection Authorities. Luxembourg: Publications Office of the European Union.

Farber, Daniel A. and Anne Joseph O'Connell. 2010. "Introduction: A Brief Trajectory of Public Choice and Public Law," in Daniel A. Farber and Anne Joseph O'Connell, eds., Research Handbook on Public Choice and Public Law. Cheltenham, UK and Northampton, MA: Edward Elgar Publishing.

Farnsworth, E. Allan. 2008. "Comparative Contract Law," in Mathias Reimann and Reinhard Zimmermann, eds., The Oxford Handbook of Comparative Law. Oxford: Oxford University Press.

Ferreres Comella, Víctor. 2011. "The Rise of Specialized Constitutional Courts," in Tom Ginsburg and Rosalind Dixon, eds., Comparative Constitutional Law. Cheltenham, UK and Northampton, MA: Edward Elgar Publishing.

Franceschet, Susan and Jordi Díez. 2012. "Thinking about Politics and Policy-Making in Contemporary Latin America," in Jordi Díez and Susan Franceschet, eds., Comparative Public Policy in Latin America. Toronto: University of Toronto Press.

Fromont, Michel. 2006. Droit administratif des États européens. Paris: Presses Universitaires de France.

Gadinis, Stavros. 2015. Three Pathways to Global Standards: Private, Regulator, and Ministry Networks, 109 American Journal of International Law 1-57.

Gardbaum, Stephen. 2003. "The 'Horizontal Effect' of Constitutional Rights," 102 Michigan Law Review 387-459.

Gargarella, Robert, ed. 2006. Courts and Social Transformation in New Democracies. Burlington, VT: Ashgate.

Garrett, Geoffrey, Frank Dobbin, and Beth A. Simmons. 2008. "Conclusion”, in Beth A. Simmons, Frank Dobbin, and Geoffrey Garrett, eds., The Global Diffusion of Markets and Democracy. Cambridge: Cambridge University Press.

Gauri, Varun and Daniel Brinks, eds. 2008. Courting Social Justice: Judicial Enforcement of Social and Economic Rights in the Developing World. Cambridge: Cambridge University Press. 
Gidi, Antonio. 2003. "Class Actions in Brazil-A Model for Civil Law Countries," 51 American Journal of Comparative Law 311-405.

Gidi, Antonio. 2012. "The Recognition of U.S. Class Action Judgments Abroad: The Case of Latin America," 37 Brooklyn Journal International Law 893-965.

Gierke, Otto. 1977. Associations and Law: The Classical and Early Christian Stages. Translated and edited by George Hieman. Toronto: University of Toronto Press.

Gilardi, Fabrizio. 2010. "Who Learns from What in Policy Diffusion Processes?" 54 American Journal of Political Science 650-66.

Gillespie, John Stanley. 2006. Transplanting Commercial Law Reform: Developing a "Rule of Law" in Vietnam. Burlington, VT: Ashgate.

Ginsburg, Tom. 2008. "Administrative Law and the Judicial Control of Agents in Authoritarian Regimes," in Tom Ginsburg and Tamir Moustafa, eds., Rule by Law: The Politics of Courts in Authoritarian Regimes. New York: Cambridge University Press.

Ginsburg, Tom and Tamir Moustafa. 2008. "Introduction: The Functions of Courts in Authoritarian Politics," in Tom Ginsburg and Tamir Moustafa, eds., Rule by Law: The Politics of Courts in Authoritarian Regimes. New York: Cambridge University Press.

Glenn, Patrick H. 2008. "Comparative Legal Families and Comparative Legal Traditions," in Mathias Reimann and Reinhard Zimmermann, eds., The Oxford Handbook of Comparative Law. Oxford: Oxford University Press.

Glenn, Patrick H. 2011. Legal Traditions of the World. 4th ed. Oxford: Oxford University Press.

Goodnow, Frank J. 1893. Comparative Administrative Law: An Analysis of the Administrative Systems, National and Local, of the United States, England, France and Germany. New York: J.P. Putnam's.

Graziadei, Michele. 2003. "The Functionalist Heritage," in Pierre Legrand and Roderick Munday, eds., Comparative Legal Studies: Traditions and Transitions. Cambridge: Cambridge University Press.

Graziadei, Michele. 2008. "Comparative Law as the Study of Transplants and Receptions," in Mathias Reimann and Reinhard Zimmermann, eds., The Oxford Handbook of Comparative Law. Oxford: Oxford University Press.

Grunewald, Mark H. 1988. "Freedom of Information Act Dispute Resolution," 40 Administrative Law Review 1-65.

Halberstam, Daniel. 2012. "Federalism: Theory, Policy, Law," in Michel Rosenfeld and András Sajó, eds., The Oxford Handbook of Comparative Constitutional Law. Oxford: Oxford University Press.

Halliday, Terence C. and Bruce G. Carruthers. 2009. Bankrupt: Global Lawmaking and Systemic Financial Crisis. Stanford, CA: Stanford University Press.

Hayward, J.E.S. 1960. "Solidarist Syndicalism: Durkheim and Duguit," 8 Sociological Review 17-36 and $185-202$.

Hill, Jonathan. 1989. "Comparative Law, Law Reform and Legal Theory," 9 Oxford Journal of Legal Studies 101-15.

Hirschl, Ran. 2005. "The Question of Case Selection in Comparative Constitutional Law," 53 American Journal of Comparative Law 125-55.

Hirschl, Ran. 2014. Comparative Matters: The Renaissance of Comparative Constitutional Law. Oxford: Oxford University Press.

Holzinger, Katharina, Christoph Knill, and Thomas Sommerer. 2008. "Environmental Policy Convergence: The Impact of International Harmonization, Transnational Communication, and Regulatory Competition," 62 International Organization 553-87.

Huntington, Samuel P. 1991. The Third Wave: Democratization in the Late Twentieth-Century. Norman, OK: University of Oklahoma Press.

Hutter, Bridget M. 1988. The Reasonable Arm of the Law? The Law Enforcement Procedures of Environmental Health Officers. Oxford: Clarendon Press.

Jianwei, Zheng. 2012. "Taming Lawless Officials with Citizen Oversight," Nov. 26. Available at http:// www.hrichina.org/en/crf/article/6403.

Kagan, Robert. 2001. Adversarial Legalism: The American Way of Law. Cambridge, MA: Harvard University Press.

Kagan, Robert A. and Lee Axelrad. 2000. Regulatory Encounters: Multinational Corporations and American Adversarial Legalism. Berkeley, CA: University of California Press.

Kahn, Alfred E. 1970. The Economics of Regulation: Principles and Institutions. Vol. 1. Cambridge, MA: MIT Press.

Kingsbury, Benedict. 2009. "The Concept of 'Law' in Global Administrative Law," 20 European Journal of International Law 23-57. 
Kingsbury, Benedict, Nico Krisch, and Richard Stewart. 2005. "The Emergence of Global Administrative Law," 68 Law and Contemporary Problems 15-61.

Knill, Christoph. 2001. The Europeanisation of National Administrations: Patterns of Institutional Change and Persistence. Cambridge: Cambridge University Press.

Koh, Harold. 1997. "Why Do Nations Obey International Law?” 106 Yale Law Journal 2599-658.

Kommers, Donald P. and Russell A. Miller. 2012. The Constitutional Jurisprudence of the Federal Republic of Germany. 3rd ed. Durham, NC: Duke University Press.

Kröger, Markus. 2012. "Neo-mercantilist Capitalism and Post-2008 Cleavages in Economic DecisionMaking Power in Brazil," 33 Third World Quarterly 897-901.

Krygier, Martin. 2012. "Rule of Law," in Michel Rosenfeld and András Sajó, eds., The Oxford Handbook of Comparative Constitutional Law. Oxford: Oxford University Press.

Krygier, Martin. 2015. "Rule of Law (and Rechtsstaat)," in James D. Wright, editor-in-chief, International Encyclopedia of the Social \& Behavioral Sciences. 2nd ed., Vol. 20. Oxford: Elsevier.

La Porta, Rafael, Florencio Lopez-de-Silanes, Andrei Shleifer, and Robert Vishny. 1999. "The Quality of Government," 15 Journal of Law, Economics and Organization 222-79.

Langer, Máximo. 2014. "The Long Shadow of the Adversarial and Inquisitorial Categories," in Markus D. Dubber and Tatjana Hörnle, eds., The Oxford Handbook of Comparative Criminal Law. Oxford: Oxford University Press.

Laski, Harold J. 1919. Authority in the Modern State. New Haven, CT: Yale University Press.

Legrand, Pierre. 1997. "The Impossibility of Legal Transplants," 4 Maastricht Journal of European and Comparative Law 111-19.

Levi-Faur, David. 2005. "The Global Diffusion of Regulatory Capitalism," 98 Annals of the American Academy of Political \& Social Science 12-32.

Levi-Faur, David and Sharon Gilad. 2004. "The Rise of the British Regulatory State: Transcending the Privatization Debate," 31 Comparative Politics 105-24.

Lijphart, Arend. 1999. Patterns of Democracy: Government Forms and Performance in Thirty-Six Countries. New Haven, CT: Yale University Press.

Linos, Katerina. 2013. The Democratic Foundations of Policy Diffusion: How Health, Family, and Employment Laws Spread Across Countries. Oxford: Oxford University Press.

MacCormick, Neil. 1999. Questioning Sovereignty: Law, State and Nation in the European Commonwealth. Oxford: Oxford University Press.

Maggetti, Marino and Fabrizio Gilardi. 2015. "Problems (and Solutions) in the Measurement of Policy Diffusion Mechanisms," 35 Journal of Public Policy 1-21.

Majone, Giandomenico. 1994. "The Rise of the Regulatory State in Europe," 17 West European Politics $77-101$.

Mannori, Luca and Bernardo Sordi. 2001. Storia del diritto amministrativo. Roma: Editori Laterza.

Mashaw, Jerry L. 2012. Creating the Administrative Constitution: The Lost One Hundred Years of American Administrative Law. New Haven, CT: Yale University Press.

Mattli, Walter and Tim Büthe. 2003. "Setting International Standards: Technological Rationality or Primacy of Power?" 56 World Politics 1-42.

May, Peter J. 2003. "Performance-Based Regulation and Regulatory Regimes: The Saga of Leaky Buildings," 25 Law and Policy 381-401.

May, Peter J. and Søren Winter. 2000. "Reconsidering Styles of Regulatory Enforcement: Patterns of Danish Agro-environmental Inspection," 22 Law and Policy 143-73.

Merryman, John Henry. 1985. The Civil Law Tradition: An Introduction to the Legal Systems of Western Europe and Latin America. 2nd ed. Stanford, CA: Stanford University Press.

Michaels, Ralf. 2008. "The Functional Method of Comparative Law," in Mathias Reimann and Reinhard Zimmerman, eds., The Oxford Handbook of Comparative Law. Oxford: Oxford University Press.

Monateri, P.G. 1997-1998. "Everybody's Talking: The Future of Comparative Law," 21 Hastings International and Comparative Law Review 825-46.

Morag-Levine, Noga. 2003. Chasing the Wind: Regulating Air Pollution in the Common Law State. Princeton, NJ: Princeton University Press.

Moustafa, Tamir. 2007. The Struggle for Constitutional Power: Law, Politics, and Economic Development in Egypt. Cambridge: Cambridge University Press.

Nelken, David. 2003. "Comparatists and Transferability," in Pierre Legrand and Roderick Munday, eds., Comparative Legal Studies: Traditions and Transitions. Cambridge: Cambridge University Press.

Nelson, James D. 2015. "The Freedom of Business Association,” 115 Columbia Law Review 461-513. 
Nicola, Fernanda G. 2015. "The Politicization of Legal Expertise in the TTIP Negotiations," 78 Law and Contemporary Problems 175-204.

Örücü, Esin. 2004. The Enigma of Comparative Law: Variations on a Theme for the Twenty-First Century. Leiden: Koninklijke Brill N.V.

Palmer, Vernon Valentine. 2005. "From Lerotholi to Lando: Some Examples of Comparative Law Methodology," 53 American Journal of Comparative Law 261-90.

Pargendler, Mariana. 2012. "The Rise and Decline of Legal Families," 60 American Journal of Comparative Law 1043-74.

Patroni, Viviana and Ruth Felder. 2012. "Turbulent Times: Structural Reforms, Crisis, and Labour Policy in Argentina, 1990s-2000s," in Jordi Diez and Susan Franceschet, eds., Comparative Public Policy in Latin America. Toronto: University of Toronto Press.

Rabel, Ernst. [1924] 1967. "Aufgabe und Notwendigkeit der Rechtsvergleichung," 13 Rheinische Zeitschrift für Zivil- und Prozeßrecht 279-301, reprinted in Hans G. Leser ed., Ernst Rabel: Gesammelte Aufsätze. Vol. 3. Tübingen: J.C.B. Mohr (Paul Siebeck).

Reif, Linda C. 2011. "Transplantation and Adaptation: The Evolution of the Human Rights Ombudsman," 31 Boston College Third World Law Journal 269-310.

Reimann, Mathias. 2002. "The Progress and Failure of Comparative Law in the Second Half of the Twentieth Century," 50 American Journal of Comparative Law 671-700.

Riles, Annelise. 1999. "Wigmore's Treasure Box: Comparative Law in the Era of Information," 40 Harvard International Law Journal 221-83.

Risley, Amy. 2015. Civil Society Organizations, Advocacy, and Policymaking in Latin American Democracies: Pathways to Participation. New York: Palgrave Macmillan.

Romano, Santi. 1946. L'Ordinamento Giuridico. Firenze: Sansoni.

Rose-Ackerman, Susan and Peter Lindseth, eds. 2010. Comparative Administrative Law. Cheltenham, UK and Northampton, MA: Edward Elgar Publishing.

Saiegh, Sebastian M. 2010. "Active Players or Rubber Stamps? An Evaluation of the Policymaking Role of Latin American Legislature," in Carlos Scarascini, Ernesto Stein, and Mariano Tommasi, eds., How Democracy Works: Political Institutions, Actors and Arenas in Latin American Policymaking. Washington, DC: Inter-American Development Bank.

Schepel, Harm and Josef Falke. 2000. Legal Aspects of Standardisation in the Member States of the EC and EFTA: Comparative Report. Vol. 1. Luxembourg: Office for Official Publications of the European Communities.

Schill, Stephan W. ed. 2010. International Investment Law and Comparative Public Law. Oxford: Oxford University Press.

Schlesinger, Rudolf B., gen. ed. 1968. Formation of Contracts: A Study of the Common Core of Legal Systems. Vols. 1 and 2. Dobbs Ferry, NY: Oceana Publications, Inc.

Schmitter, Philippe C. 1974. "Still the Century of Corporatism?" 36 Review of Politics 85-131.

Schneider, Ben Ross 2010. "Business Politics and Policymaking in Contemporary Latin America," in Carlos Scarascini, Ernesto Stein, and Mariano Tommasi, eds., How Democracy Works: Political Institutions, Actors and Arenas in Latin American Policymaking. Washington, DC: Inter-American Development Bank.

Scott, Colin. 2006. "Privatization and Regulatory Regimes," in Michael Moran, Martin Rein, and Robert E. Goodin, eds., The Oxford Handbook of Public Policy. Oxford: Oxford University Press.

Scott, Joanne. 2009. "From Brussels with Love: The Transatlantic Travels of European Law and the Chemistry of Regulatory Attraction," 57 American Journal of Comparative Law 897-942.

Selznick, Philip. 1985. "Focusing Organizational Research on Regulation," in Roger Noll, ed., Regulatory Policy and the Social Sciences. Berkeley, CA: University of California Press.

Simmons, Beth A., Frank Dobbin, and Geoffrey Garrett. 2008. "Introduction: The International Diffusion of Liberalism," in Beth A. Simmons, Frank Dobbin, and Geoffrey Garrett, eds., The Global Diffusion of Markets and Democracy. Cambridge: Cambridge University Press.

Smulovitz, Catalina. 2012. "Public Policy by Other Means: Playing the Judicial Arena," in Jordi Díez and Susan Franceschet, eds., Comparative Public Policy in Latin America. Toronto: University of Toronto Press.

Spamann, Holger. 2015. "Empirical Comparative Law," 11 Annual Review of Law and Social Science 131-53.

Stewart, Richard B. 2014. "Remedying Disregard in Global Regulatory Governance: Accountability, Participation, and Responsiveness," 108 American Journal of International Law 211-70. 
Stone Sweet, Alec. 2012. "Constitutional Courts," in Michel Rosenfeld and András Sajó, eds, The Oxford Handbook of Comparative Constitutional Law. Oxford: Oxford University Press.

Suleiman, Ezra N. and John Waterbury, eds. 1990. The Political Economy of Public Sector Reform and Privatisation. Boulder, CO: Westview.

Teubner, Gunther. 1998. "Legal Irritants: Good Faith in British Law or How Unifying Law Ends up in New Divergences," 61 Modern Law Review 11-32.

Thatcher, Mark. 2007. Internationalisation and Economic Institutions: Comparing European Experiences. Oxford: Oxford University Press.

Tichenor, Daniel J. and Richard A. Harris. 2005. "The Development of Interest Group Politics in America: Beyond the Conceits of Modern Times," 8 Annual Review of Political Science 251-70.

Truman, David B. 1951. The Governmental Process: Political Interests and Public Opinion. New York: Alfred A. Knopf.

Twining, William. 2005. "Social Science and the Diffusion of Law, 32 Journal of Law and Society 203-40.

Valcke, Catherine. 2012. "Reflections on Comparative Law: Getting Inside Contract Law Methodology," in Maurice Adams and Jacco Bomhoff, eds., Practice and Theory in Comparative Law. Cambridge: Cambridge University Press.

Vande Walle, Simon. 2013. Private Antitrust Litigation in the European Union and Japan. Maklu: Antwerpen-Appledoorn.

Vellinga, Menno. 2004. "State Reform and Traditional Political Practice in Latin America," in H.J. Wiarda, ed., Authoritarian and Corporatism in Latin America-Revisited. Gainesville, FL: University of Florida Press.

Vogel, David. 1986. National Styles of Regulation. Ithaca, NY: Cornell University Press.

Vogel, Steven. 1996. Freer Markets, More Rules: Regulatory Reform in Advanced Industrial Countries. Ithaca, NY: Cornell University Press.

Volokh, Alexander. 2014. "The New Private-Regulation Skepticism: Due Process, Non-Delegation, and Antitrust Challenges," 37 Harvard Journal of Law \& Public Policy 931-1007.

Watson, Alan. 1974. Legal Transplants. Charlottesville, VA: University Press of Virginia.

Weyland, Kurt. 2006. Bounded Rationality and Policy Diffusion: Social Sector Reform in Latin America. Princeton, NJ: Princeton University Press.

Whytock, Christopher A. 2004. "Thinking Beyond the Domestic-International Divide: Toward a Unified Concept of Public Law," 36 Georgetown Journal of International Law 155-93.

Xiao, Weibing. 2012. Freedom of Information Reform in China: Information Flow Analysis. New York: Routledge.

Yeung, Karen. 2010. “The Regulatory State,” in Robert Baldwin, Martin Cave, and Martin Lodge, eds., The Oxford Handbook of Regulation. Oxford: Oxford University Press.

Ziller, Jacques. 1993. Administrations comparées: Les systems politico-administratifs de l'Europe des Douze. Paris: Montchrestien.

Zimmermann, Reinhard. 2008. "Comparative Law and the Europeanization of Private Law," in Mathias Reimann and Reinhard Zimmermann, eds., The Oxford Handbook of Comparative Law. Oxford: Oxford University Press.

Zimmermann, Reinhard. 2009. "The Present State of European Private Law," 57 American Journal of Comparative Law 479-512.

Zuvanic, Laura and Mercedes Iacoviello, with Ana Laura Rodríguez Gusta. 2010. "The Weakest Link: The Bureaucracy and Civil Service Systems in Latin America," in Carlos Scarascini, Ernesto Stein, and Mariano Tommasi, eds., How Democracy Works: Political Institutions, Actors and Arenas in Latin American Policymaking. Washington, DC: Inter-American Development Bank.

Zweigert, Konrad. 1951. "Il diritto comparato a servizio dell'unificazione giuridica europea," 4 Nuova Rivista di Diritto Commerciale Diritto dell'Economica Diritto Sociale 183-89.

Zweigert, Konrad and Hein Kötz. 1998. Introduction to Comparative Law. 3rd rev. ed. Translated by Tony Weir. Oxford: Clarendon Press. 
Francesca Bignami - 9781782545613 